\title{
Katılım Bankaları Kar Payı Oranlarını Etkileyen Faktörler: Mevduat Faiz Oranları ve Kar Payı Oranlarının Yakınlığıyla İlgili Bir Değerlendirme \\ (Factors Affecting Participation Banks' Profit Share Rates: an Assessment of the Proximity of the Deposit Interest Rates and Profit Share Rates)
}

\section{Mehmet Kemalettin ÇONKAR iD a Halilibrahim GÖKGÖZ (iD b}

a Afyon Kocatepe Üniversitesi, İktisadi ve İdari Bilimler Fakültesi, İşletme Bölümü, Afyon, Türkiye. mkconkar@gmail.com b Afyon Kocatepe Üniversitesi, İktisadi ve İdari Bilimler Fakültesi, İşletme Bölümü, Afyon, Türkiye. hgokgoz@aku.edu.tr

\begin{tabular}{l} 
MAKALE BİLGísi \\
\hline Anahtar Kelimeler: \\
İslami bankacılık \\
Kar payı Oranı \\
Kırılmalı Eşbütünleşme \\
Fourier ADF \\
Fourier Granger \\
Gönderilme Tarihi 1 Eylül \\
2020 \\
Revizyon Tarihi 27 Aralık \\
2020 \\
Kabul Tarihi 7 Mart 2021
\end{tabular}
ÖZET

Amaç - Katılım bankalarının uyguladığ 1 fon kullandırma yöntemleri içerisinde murabaha'nın payı \%90'1 aşmaktadır. Söz konusu yöntemle ilgili olarak en çok yapılan tartışma ise bu bankaların fon kullandırmada uyguladıkları vade farkının geleneksel bankaların uyguladı̆̆ı faiz oranıyla hemen hemen aynı seviyelerde olduğu ve aynı yönde seyrettiğidir. Bu bağlamda çalışmamızda hem bu iddianın ekonometrik olarak test edilmesi hem de bu olgudan hareketle murabaha yönteminin faizli kredi benzeri olduğu iddialarına ilişkin bir değerlendirme ve öneri yapılması amaçlanmıştır.

Yöntem - Bu amaçla katılım bankaları ortalama 1, 3, 6 ve 12 ay vadeli kar payı oranları, geleneksel bankalar 1, 3, 6 ve 12 ay vadeli ağırlıklı ortalama mevduat faizi oranları, TÜFE ve USD/TL döviz kuru arasındaki ilişki yapısal kırılmaları dikkate alan tek kırılmalı eşbütünleşme ve Fourier Granger nedensellik analizleriyle test edilmiştir. Analiz için kullanılan veri seti Ocak 2003 ile Ocak 2018 dönemini kapsayan aylık verilerden oluşmaktadır.

Bulgular - Seriler arasında eşbütünleşme ilişkisi olmadığı gözlenmiştir. 1, 3, 6, 12 ay vadeli mevduat faizi oranlarından 1, 3, 6, 12 ay vadeli kar payı oranlarına doğru aynı vadelerde tek yönlü nedensellik ilişkisinin olduğu ve USD/TL döviz kuru ile TÜFE'den kar payı oranlarına doğru nedensellik ilişkisi olmadığı görülmüştür.

Makale Kategorisi:

Araştırma Makales

Tartışma - Katılım bankalarının faiz riskine maruz kaldığı̆, bu riske karşı önlem alması gerektiği ve faizden kaçınmak isteyen katılım bankalarındaki mevduat sahiplerinin de karar verirken TÜFE ve USD/TL döviz kuru makroekonomik değişkenlerinden ziyade faizi göz önünde bulundurması gerektiği belirtilebilir. Çalışmada, katılım bankaları vade farklarının geleneksel bankaların faiz oranlarıyla aynı yönde hareket etmesi ve hemen hemen aynı olması ile ilgili bir değerlendirme de yapılmıştır. Konuyla ilgilenenlerin çoğu 'murabaha' yönteminin aslında faizsizlik iddiasına uymadı̆̆ını ileri sürmektedir. Çalışmada ise bu olguya ters yönden de bakılabileceği, dolayısıyla devletin sıkı düzenlemeleri ve denetimi altında çalışan geleneksel bankalardaki mevduat ve kredi faizinin riba olup olmadığının tartışılması gerektiği belirtilmiştir.

\section{ARTICLE INFO}

ABSTRACT

\section{Keywords:}

Islamic Banking

Profit Share Rate

Fractured Cointegration

Fourier ADF

Fourier Granger

Received 1 September 2020

Revised 27 December 2021

Accepted 7 March 2021

Article Classification:

Research Article
Purpose - The share of murabaha among the funding methods applied by participation banks exceeds $90 \%$. The most common discussion regarding the method in question is that the maturity difference applied by these banks in the use of funds is almost at the same level with the interest rate applied by traditional banks and it is in the same direction. In this context, in this study, it was aimed to test this claim econometrically and to make an evaluation and suggestion regarding the claims that the murabaha method is like a loan with interest, based on this fact.

Design/Methodology/Approach - The relationship between profit share rates and deposit interest rates, the CPI and the USD / TL exchange rate has been tested with single-break cointegration and Fourier Granger causality analyzes considering structural breaks. For this purpose, participation banks average 1 , 3, 6 and 12-month dividend rates, traditional banks 1, 3, 6 and 12-month maturity weighted average deposit rates, the relationship between CPI and USD / TL exchange rate has been tested with single-break cointegration and Fourier Granger causality analyzes considering structural breaks. The data set used for the analysis consists of monthly data covering the period January 2003 and January 2018.

Findings - It was determined that there was no cointegration relationship. It is determined, that there is one way casuality relationship from deposit interest rates in 1, 3, 6, 12 month(s) maturities to profit share rates in 1, 3, 6, 12 month(s) maturities in each maturity levels and there is no causal relationship between USD / TL exchange rate and CPI to profit share rates. 
Discussion - It can be stated that participation banks are exposed to interest risk, they should take measures against this risk, and depositors in participation banks who want to avoid interest should also consider interest rate rather than macroeconomic variables of CPI and USD / TL exchange rate when making decisions. In the study, an evaluation has been made about the fact that the interest rates of participation banks move in the same direction with the interest rates of traditional banks and are almost the same. Most of those who are interested in the issue argue that the "murabaha" method does not actually comply with the interest-free claim. In the study, it was stated that this phenomenon can be viewed from the opposite side, so it should be discussed whether the deposit and loan interest rates in traditional banks operating under the strict regulations and control of the state should be discussed.

\section{GİRIŞ}

Ribanın (faizin) İslam'da yasak olması nedeniyle faizsiz bankacılık iddiasıyla hayata geçen 'katılım bankaları', bu amaçla birçok ürün geliştirmişlerdir. Teorik olarak fon kullandırmaya yönelik birçok ürün sayılmakla birlikte, uygulamada en yoğun olarak kullanılan ürün, kar/zarar ortaklığı esaslı yöntemler değil 'murabaha' isimli fon kullandırma yöntemidir.

Çalışmamızda, konuyla ilgili olarak gözden geçirebildiğimiz çalışmalardan farklı olarak, kar payı oranları ile mevduat faizi oranları ve makroekonomik değişkenler arasındaki ilişki yapısal kırılmalar dikkate alınarak incelenmiştir. Bir VAR modelinde, modeldeki değişkenlerde dikkate alınmayacak yapısal kırılmalar, modelin ortaya koyduğu sonuçların gerçekten sapmasına neden olabilir. Ancak kurulacak modellerde yapısal kırılmaların keskin bir biçimde olduğunu dikkate almak da gerçeği yansıtmayabilir. Bu nedenle araştırmadaki değişkenlerle kurulacak VAR modelinde yapısal kırılmaları keskin olmayan biçimde (Fourier) dikkate almak sonuçların gerçekten daha az sapmasını sağlayabilir. Bu yüzden kar payının; mevduat faizi, TÜFE ve USD/TL ile ilişkisinin yapısal kırılmaları dikkate alan analizlerle incelenmesi önem arz etmektedir.

Katılım bankalarında fon kullandırma yöntemleri arasında murabaha'nın payı \%90'ı aşmaktadır. Söz konusu yöntemle ilgili olarak en çok yapılan tartışma ise bu bankaların fon kullandırmada uyguladıkları vade farkının geleneksel bankaların uyguladığı faiz oranıyla hemen hemen aynı seviyelerde olduğu ve aynı yönde seyrettiğidir. Çalışmamızda hem bu iddia ekonometrik olarak test edilmiş hem de bu olgudan hareketle murabaha yöntemi ve faiz ile ilgili bir değerlendirme yapılmıştır.

Birçok yazar; belirttiğimiz durumun ortaya çıktı̆̆ı 'murabaha' uygulamasının aslında faizsiz bir yöntem olarak kabul edilmesi hususunu tartışmaktadırlar. Biz ise aynı gerçeğe diğer taraftan bakarak; devletin çok ciddi düzenlemeleri çerçevesinde faaliyet gösteren klasik bankalardaki mevduat ve kredi faizinin Kur'an-1 kerimde yasaklanan riba ile aynı şey olup olmadığının da tartışılmasının gerektiğini belirtmek istiyoruz. Bazı alimler 'Kur'an' da yasaklanan ribanın katlı veresiye faizi olduğunu buna mukabil ilk akit sırasındaki fazlalığın (faizin) riba kapsamında olmadığını' belirtmişlerdir.

Her çeşit banka faizinin İslam'ın yasakladığı riba olduğu biçimindeki anlayış ülkemizde genel kabul görmüş bakış açısı olarak belirtilebilir. Bu yöndeki görüşlerin özü ve özetini 20. yüzyıl Türkiye'sinin en önde gelen tefsir alimi Elmalı Hamdi Yazır'ın ‘Hak Dini, Kur’an Dili' adlı tefsirinde bulabiliriz.

Söz konusu eleştirilerin tümü iki taraflı borç verme ilişkisi çerçevesinde bir anlam ifade edebilir. Halbuki günümüzde faiz deyince banka dediğimiz kurumlar akla gelir öncelikle. Burada ise üç taraflı bir ilişki söz konusudur: Bankaya tasarruflarını yatıran mevduat sahipleri, aracı kurum olarak banka ve bankanın kredi verdiği işletme veya fertler. Buradaki faiz yasağına ilişkin gerekçelerle ilgili olarak söylenmesi gereken esas husus şudur: Bütün bu ve benzeri eleştiriler klasik banka mevduat faizi ve kredi faiziyle ilgili olarak geçerliyse, faizsiz bankacılık yaptığı ifade edilen katılım bankalarının mevduata verdiği kar payı ve kredi kullandırmada uyguladığı vade farkının söz konusu olduğu 'murabaha' uygulaması için de aynen geçerlidir. Tefsirde belirtilen gerekçelerin tümü iki taraflı borç verme ilişkisi çerçevesinde anlamlı olabilir.

Değerlendirmemizin başlangıcında da katılım bankacılığı uygulamasının başlamasından çok önceleri bile klasik bankalardaki mevduat ve kredi faizinin Kur'an'da yasaklanan riba ile aynı şey olmadığını savunan birçok alim olduğunu belirtmiştik. Katılım bankacılığının kredi kullandırma uygulamasının \%90'ından fazlasının 'murabaha' yöntemi olduğu, bu yöntemde ise bankaya fon yatıranlara ödenen kar payı ve kredi kullananlara uygulanan vade farkı oranlarının klasik banka mevduat ve kredi faizleriyle çok yakın ve aynı yönde seyrettiği gerçeğinin açık biçimde görülmesinden sonra bu değerlendirmenin daha da büyük önem kazandığını rahatlıkla söyleyebiliriz. 
Bizi bu yönde bir tartışmanın anlamlı olacağı kanısına yönelten diğer bir hususun son zamanlarda ciddi din alimlerinden bazılarının makale ve kitaplarındaki değerlendirmeleri olduğunu belirtmek isteriz.

Değerlendirmemizi aşağıdaki sorularla sonuçlandırmanın uygun olacağı kanısına varmış bulunuyoruz. Bu durumda katılım bankalarının fon kullandırma uygulamaları içinde çok geniş yer tutan murabahayı fıkhi açıdan eleştirenlerin şu sorulara net bir cevap üretmeleri gerekmektedir: Kısa vadeli kredi için fikhi açıdan murabahadan daha uygun bir seçenek öneriyor musunuz? Aksi halde geleneksel bankaların devletin sıkı düzenlemeleri ve denetimi çerçevesinde yürüttükleri kısa vadeli kredi uygulamasındaki faizin riba olmadığıyla ilgili daha açık ve net bir tavır ortaya koymak gerekmez mi?

\section{LITERATÜR}

Geleneksel bankaların mevduat faizi oranları ile İslami bankalar kar payı oranları arasındaki ilişkiye ilişkin literatür incelendiğinde konuyla ilgili çok sayıda çalışma yapıldığ 1 gözlenmiştir. İncelenen çalışmaların hepsinde de iki faktörün aynı yönde ve birbirine çok yakın seyrettikleri belirlenmiştir. Mevduat faizi oranları ve kar payı oranlarından hangisinin hangisini etkilediği ile ilgili olarak fikir birliği olmayıp; genel olarak mevduat faiz oranlarının kar payı oranlarını etkilediği; kar payı oranlarının mevduat faizi oranlarını etkilemediği savunulmuştur. Konuya ilişkin çalışmalar kronolojik olarak incelenmiş ve ayrıntıları aşağıda sunulmuştur.

Haron ve Ahmad (2000) tarafından yapılan çalışmada Malezya'da mevduat faiz oranları ve kar payı oranlarının İslami bankacılık sistemine yatııılan fonlar üzerindeki etkisi araştırılmıştır. Çalışmada Ocak 1984Aralık 1998 dönemi geleneksel banka mevduatları tutarı, İslami banka mevduatlarının beklenen kar oranı, geleneksel bankaların vadeli mevduat faiz oranı, İslami bankaların mevduatları tutarı, İslami banka mevduatlarının beklenen kar oranı ve geleneksel bankaların mevduat faiz oranı aylık verilerinden oluşan veri seti kullanılmıştır. Yapılan regresyon analizleri sonucunda geleneksel bankaların mevduat faiz oranı ile İslami banka mevduat tutarı arasında negatif ilişki, İslami banka mevduat kar payı oranı ile mevduat tutarı arasında pozitif ilişki ve geleneksel banka mevduat tutarları ile İslami bankaları mevduat tutarları arasında negatif ilişki olduğu gözlenmiştir.

2003 yılında Kaleem ve Isa tarafından yapılan çalışmada Malezya' da İslami ve geleneksel bankacılık araçları arasındaki ilişki Granger nedensellik analiziyle test edilmiştir. Çalışmanın veri setini Ocak 1994-Aralık 2002 arası ticari bankalar ve finans şirketleri altında sunulan 1, 3, 6, 9 ve 12 aylık İslami ve geleneksel mevduat getirilerinin aylık verileri oluşturmaktadır. Analiz sonucunda genel olarak geleneksel mevduat getirilerinin İslami mevduat getirilerinin nedeni olduğu gözlenmiştir.

Bacha (2004) tarafından yapılan çalışmada geleneksel ve İslami bankaların getiri oranları ve mevduat miktarları arasındaki ilişki test edilmiştir. Çalışmada Ocak 1994-Temmuz 2003 dönemi mevduat miktarları ve getiri oranları aylık verileri kullanılmıştır. Yapılan regresyon ve Granger nedensellik analizi sonucunda geleneksel banka faiz oranı ile İslami bankaların kar payı oranları arasında ilişki olduğu ve geleneksel bankaların faiz oranlarından İslami bankaların kar payı oranlarına doğru güçlü ve tek yönlü nedensel ilişki olduğu gözlenmiştir. Ayrıca analiz sonucunda getiri oranlarına benzer sonuçların olduğu ve geleneksel bankaların mevduat tutarının İslami bankaların mevduat tutarının nedeni olduğu görülmüştür.

2009 yılında Chong ve Liu tarafından yapılan çalışmada geleneksel ve İslami bankaların mevduat getiri oranları ve mevduat tutarları arasındaki ilişki incelenmiştir. Çalışmada Nisan 1995-Nisan 2004 dönemi geleneksel ve İslami bankaların 1 aydan 12 aya kadar mevduat getiri oranları aylık verileri veri seti olarak kullanılmıştır. Yapılan Granger analizi sonucunda geleneksel bankaların mevduat getiri oranlarından (1 aydan 12 aya kadar) İslami bankaların mevduat getiri oranlarına doğru tek yönlü nedensel ilişki olduğu tespit edilmiştir. Elde edilen bulgular İslami bankacılık uygulamalarının pratikte faizsiz olmadığını gösterdiği ve İslami bankacılığın geleneksel bankacılığa ve İslami mevduatların geleneksel banka mevduatlarına çok benzediği belirtilmiştir. Ayrıca çalışma sonucunda İslami bankaların geleneksel bankalarla benzer şekilde denetlenip düzenlenmesi gerektiği belirtilmiştir.

Zainol ve Kassim (2010) tarafından yapılan çalışmada İslami bankaların 3 aylık kar payı oranları ile geleneksel bankalar 3 aylık mevduat faizi arasındaki ilişki ve her iki bankanın toplam mevduatları arasındaki ilişki test edilmiştir. Analiz için Ocak 1997-Ekim 2008 dönemi aylık verileri kullanılmıştır. Çalışmada VAR, VECM, eşbütünleşme ve Granger nedensellik analizleri uygulanmıştır. Analiz sonucunda 3aylık vadeli mevduat faizi 
oranları ile İslami banka kar payı oranları arasında çift yönlü nedensellik ilişkisi tespit edilmiştir. Sonucun bu şekilde çıkması, literatürdeki benzer çalışmaların sonuçlarından farklılaştığını göstermektedir.

2013 yılında Ito tarafından yapılan çalışmada Malezya mevduat piyasasında İslami bankacılık getiri oranları ile mevduat faiz oranları arasındaki ilişi test edilmiştir. Çalışmada Mayıs 2005-Aralık 2012 dönemi 1, 3, 6 ve 12 aylık mevduat faiz oranları ile aynı vadelerdeki İslami mevduat getiri oranları aylık verileri veri seti olarak kullanılmıştır. Yapılan Granger nedensellik analizi neticesinde literatürdeki benzer çalışmaların tersine İslami getiri oranlarından mevduat faiz oranlarına doğru nedensellik ilişkisi tespit edilmiştir.

Avcı ve Aktaş (2015) tarafından katılım bankalarının kar payı ödemeleri ile mevduat bankalarının faiz ödemelerinin birbirine yakın olmasının nedenleri araştırılmıştır. Çalışmada 2010-2014 dönemi katılım bankalarının kullandırdıkları fon yöntemleri trend analizi yöntemiyle incelenmiştir. Analiz sonucunda katılım bankaları kar payı oranlarının mevduat bankaları faiz oranlarına eşit denebilecek derecede yakın olmasının sebebinin, katılım bankalarının murabaha fon kullandırma yöntemini ağırlıklı olarak kullanması olduğu belirtilmiştir.

Cevik ve Charap (2015) tarafından yapılan çalışmada Malezya ve Türkiye'de geleneksel ve İslami getiriler arasındaki ilişki incelenmiştir. Söz konusu çalışmada analiz için Ocak 1997- Ağustos 2010 dönemi Malezya ve Türkiye geleneksel, İslami mevduat getirileri ve enflasyon oranları aylık verileri kullanılmıştır. Analiz sonucunda İslami mevduat getirilerinin geleneksel mevduat getirileri ile eşbütünleşik olduğu; eşbütünleşme analizine TÜFE dahil edildiğinde Malezya'da eşbütünleşik olduğu ancak Türkiye'de eşbütünleşik olmadığ1 gözlenmiştir. Ayrıca her iki ülkede de geleneksel mevduat getirilerinden İslami mevduat getirilerine doğru tek yönlü Granger nedensel ilişki olduğu tespit edilmiştir.

2016 yılında Ata ve diğ. tarafından yapılan çalışmada kar payı oranları ile mevduat faizi oranları arasındaki ilişki test edilmiştir. Bu amaçla Ocak 2004-Aralık 2014 dönemi 1, 3, 6 ve 12 ay vadeli kar payı oranları ile 1, 3, 6 ve 12 ay vadeli mevduat faizi oranları aylık verileri veriseti olarak kullanılmıştır. Değişkenler arasındaki ilişki Hacker ve Hatemi nedensellik analiziyle test edilmiş, analiz sonucunda 1, 3 ve 6 aylık vadelerde mevduat faiz oranlarından kar payı oranlarına doğru tek yönlü; 12 aylık vadede ise çift yönlü nedensel ilişki olduğu tespit edilmiştir.

Gül ve diğ. (2017) tarafından yapılan çalışmada katılım bankalarının fon kaynaklarını etkileyen faktörlerin ve klasik bankalarla ilişkilerinin tespiti amaçlanmıştır. Çalışmada Ocak 2005-Mart 2013 dönemi ortalama kar payı, ortalama mevduat faizi, TÜFE, katılım bankaları mevduatı, ticari bankaların mevduat verilerinden oluşan veriseti kullanılmıştır. Yapılan Johansen eşbütünleşme analizi sonucunda, faiz oranı ve kar payı arasında pozitif yönde bir ilişki olduğu; kar payı ve faiz oranının katılım bankalarının fonlarını etkilediği tespit edilmiştir.

2017 yılında Minny ve Görmüş tarafından yapılan çalışmada faiz oranındaki değişikliklerin katılım bankalarının karlılığına etkisi araştırılmıştır. Çalışmada 2008 yılı 1. çeyreği ile 2016 yılı 3. Çeyreği arası 3'er aylık 3 katılım bankasının toplam aktifleri, kredileri, toplam kar, Merkez bankası faiz oranı ve hesaplanan ROA verileri veriseti olarak kullanılmıştır. Yapılan panel eşbütünleşme analizi sonucunda faiz oranı ile katılım bankalarının karlılığı arasında eşbütünleşme ilişkisi olduğu gözlenmiştir. Ayrıca sonucun bu şekilde çıkmasının katılım bankalarının konvansiyonel bankalarla birlikte hareket etmeleri anlamına geldiği belirtilmiştir.

Zengin ve diğ. (2018) tarafından yapılan çalışmada katılım bankalarının dağıttığı TL, USD/TL ve EU/TL aylık kar payı oranlarının karşılaştırmalı analizi yapılmıştır. Analiz için Albaraka Türk, Kuveyt Türk ve Türkiye Finans Katılım bankalarının Ocak 2010-Ocak 2018 Dönemi arası aylık TL, USD/TL ve EU/TL aylık kar payı oranları veriseti olarak kullanılmıştır. Yapılan nonparametric testler sonucunda katılım bankalarının dağıttıkları kar payı oranları arasında anlamlı farklılık olduğu gözlenmiştir. Analiz sonucunda TL kar payı oranında Albaraka Türk, USD/TL kar payı oranında Türkiye Finans ve EU/TL kar payı oranında Kuveyt Türk katılım bankalarının daha yüksek kar payı dağıttıkları görülmüştür.

Topdağ ve Işık (2019) tarafından yapılan çalışmada 1, 3, 6 ve 12 aylık ortalama kar payı oranları, mevduat faizi oranları ve enflasyon arasındaki ilişki Johansen eşbütünleşme analizi, Granger nedensellik analizi ve Toda Yamamoto nedensellik analizi ile test edilmiştir. Çalışmada analiz için Ocak 2003-Eylül 2017 dönemi aylık veriseti kullanılmıştır. Analiz sonucunda 1, 3, 6 ve 12 aylık vadelerde kar payı oranları, mevduat faizi oranları 
ve enflasyon arasında eşbütünleşme ilişkisi olduğu ve mevduat faizi oranlarından kar payı oranlarına doğru tek yönlü Toda Yamamoto nedensel ilişkisi olduğu gözlenmiştir. Ayrıca 1, 3 ve 12 aylık vadelerde mevduat faizi oranlarından kar payı oranlarına doğru tek yönlü granger nedensel ilişkisi olduğu tespit edilmiştir.

Tura ve Kaya (2019) tarafından yapılan çalışmada katılım bankaları kar payı oranları ile geleneksel bankaların mevduat faizi oranları arasındaki ilişki VAR, Johansen eşbütünleşme ve Granger nedensellik analizleriyle test edilmiştir. Çalışmada Eylül 2005-Aralık 2017 dönemi katılım bankalarının aylık kar payı ödemeleri ile geleneksel bankaların aylık mevduat faizlerinin aylık verileri veriseti olarak kullanılmıştır. Analiz sonucunda kar payı oranı ile mevduat faizi oranı arasında uzun dönemli ilişki olduğu ve mevduat faizi oranından kar payı oranına doğru tek yönlü nedensellik ilişkisi olduğu gözlenmiştir. Ayrıca etki-tepki ve varyans ayrıştırma testleri sonucunun da nedensel ilişkiye paralel sonuçlar ortaya koyduğu gözlenmiştir.

Literatürde mevduat faiz oranları ile kar payı oranları arasındaki ilişkiyi zaman serisi ve panel veri analiziyle test eden çalışmaların tamamının yapısal kırılmaları dikkate almayan yöntemlerle test edildiği görülmüştür halbuki yapısal kırılmaların dikkate alınmaması sonuçların gerçeklerden sapmasına neden olabilir. Ayrıca çalışmaların çoğunda TÜFE'nin dikkate alınmadığı gözlenmiştir. Bu yüzden bu çalışmada 4 ayrı vadede mevduat faiz oranları, kar payı oranları ve TÜFE değişkenleri arasındaki ilişki yapısal kırılmaları dikkate alan analizlerle test edilecektir.

\section{YÖNTEM}

\section{1. Çalışmanın Amacı}

Katılım bankalarının fon kullandırmada uyguladıkları vade farkının geleneksel bankaların uyguladığı faiz oranıla hemen hemen aynı seviyelerde seyretmesi günümüzde en çok tartışılan konular arasındadır. Bu bağlamda çalışmada hem bu iddianın yapısal kırılmaları dikkate alan tek kırılmalı eşbütünleşme ve Fourier Granger nedensellik analizleriyle test edilmesi hem de bu olgudan hareketle murabaha yöntemi ve faiz ile ilgili bir değerlendirme yapılması amaçlanmıştır.

\subsection{Fourier ADF ve Fourier Granger Nedensellik Analizi}

Araştırmada kullanılan değişkenlerin yapısal kırılmalar içermesi olağan bir durumdur ve VAR modeli kurulan bu değişkenlerin tamamı yapısal kırılmasız değilse bu durum kurulacak VAR modelindeki diğer değişkenlerde yapısal kaymalara neden olacaktır. VAR modeli tahmininden önce değişkenlerin durağanlığı test edilir. Zaman serilerinde değişkenlerin birim kök içerip içermediğinin tespitinin yapılmasında, yapısal kırılmaları dikkate alan birden fazla model vardır. Bu modellerden bazıları; sıfır hipotezi $\left(\mathrm{H}_{0}\right)$ 'seri durağandır' olan, tek kırılmalı KPSS (Kurozumi, 2002), Çift kırılmalı KPSS (CS ve Sanso, 2007), Fourier (yumuşak kırılma) KPSS (Becker ve diğ., 2006) testleri ve sıfır hipotezi $\left(\mathrm{H}_{0}\right)$ 'seri birim köktür' olan, tek kırılmalı ADF (Zivot ve Andrews, 1992), çift kırılmalı ADF (Narayan ve Pop, 2010), fourier (yumuşak kırılma) ADF (Enders ve Lee, 2012) testleridir.

Bir VAR modelinde değişkenlerde dikkate alınmayacak yapısal kırılmalar modelin ortaya koyduğu sonuçların gerçekten sapmasına neden olabilir. Ancak kurulacak modellerde yapısal kırılmaların keskin bir biçimde olduğunu dikkate almak da gerçeği yansıtmayabilir. Bu nedenle araştırmadaki değişkenlerle kurulacak VAR modelinde yapısal kırılmaları keskin olmayan biçimde (Fourier) dikkate almak sonuçların gerçekten daha az sapmasını sağlayabilir. Enders ve Jones (2016) yumuşak kırılmaya (fourier) sahip değişkenlerdeki olası çoklu yapısal kaymalarla başa çıkılmasını sağlayan VAR modeli üzerine çalışarak bu problemi ele almıştır.

Bu amaçla Enders ve Jones (2016) VAR modelindeki değişkenlerde birden daha çok yapısal kırılma ihtimalini dikkate almak için esnek fourier formunun (Gallant, 1981) bir değişkenini kullanır. Yöntemi tanımlamada, VAR'daki değişkenlerin deterministik kısımlarının, birden çok yapısal kırılmaya sahip olduğu dikkate alınır. (Ghosrary ve diğ., 2018). Bu, değişken yit denkleminin deterministik kısmı qit olarak ifade edilebilir:

$\mathrm{q}_{\mathrm{it}}=\mathrm{x}_{\mathrm{i} 0}+\mathrm{x}_{\mathrm{i} 1} \mathrm{q}_{1 \mathrm{t}}+\mathrm{x}_{\mathrm{i} 2} \mathrm{q}_{2 \mathrm{t}}+\cdots \mathrm{x}_{\mathrm{ir}} \mathrm{q}_{\mathrm{rt}}$

Denklemde, $q_{i t,}$ zaman içerisindeki potansiyel pürüzsüz işlevleri temsil eden, $x_{i j}(j=1,2, ., r)$ parametreleri, $i$ değişkenindeki j kırılmasının boyutunu belirtir; ve $r$, i değişkenindeki kırılma sayısını belirtir. Kırılmalar keskinse, bu durumda Heaviside Göstergeleri $x_{j t}=1$ olacak şekilde kullanılabilir, aksi durumda $t>t_{j}$ ve $x_{j t}=0$ olarak kullanılır. Bununla birlikte, birden çok kırılma varsa ve bu kırılmalar küçük olma eğilimindeyse, Esnek 
Fourier Formu, xit'nin zaman içinde yumuşak fonksiyonlara sahip olmasını sağlaması daha uygun olacaktır (Ghoshray ve diğ., 2018). Enders ve Jones (2016) tarafından önerilen prosedür, aşağıdakiler tarafından verilecek değişken ( $\mathrm{yit}_{\mathrm{it}}$ ' in deterministik bölümünü ( $\left.\mathrm{q}_{\mathrm{it}}\right)$ temsil eder:

$\mathrm{q}_{\mathrm{it}}=\delta_{\mathrm{i} 0}+\sum_{\mathrm{m}=1}^{\mathrm{n}} \phi_{\mathrm{im}} \sin (2 \pi \mathrm{mt} / \mathrm{T})+\sum_{\mathrm{m}=1}^{\mathrm{n}} \psi_{\mathrm{im}} \cos (2 \pi \mathrm{mt} / \mathrm{T})$

Esnek Fourier formu içerisindeki uygun frekansların seçimi, serilerdeki yapısal kırılmaları kontrol eder. Doğrusallık testi, 2 . denklemde tüm $\phi_{\mathrm{im}}=\psi_{\mathrm{im}}=0$ değerlerinin 0 olduğu dışlama kısıtlaması için basit bir $\mathrm{F}$ testiyle yapılabilir. Denklem 2' de gösterildiği gibi $\phi$ im ve $\psi$ im'in çok değişkenli normal dağılımlara sahip olması mümkündür (Gallant, 1981). Esnek Fourier formunun olumlu yönlerinden birisi; konum, kırılma tarihlerinin sayısı ve büyüklük hakkında bilgi olmaksızın, kırılmaların yapısını taklit edebilmesidir. Bunun yanı sıra; Fourier yaklaşımı ya katkı maddesi dışı ya da inovatif tipte olabilecek yapısal kırılmalar için çalışır (Ghoshray ve diğ., 2018).

Bir Fourier-VAR modelini tahmin etmeden önce, modelde yer alan değişkenlerin birim kök içerip içermediğinin test edilmesi gerekmektedir. Enders ve Lee (2012) trigonometrik bileşenleri dahil eden uygun bir LM tabanlı birim kök testi ortaya koymuşlardır. Yöntem süreci, aşağıdaki regresyonun yt zaman serilerinde tahmin edilmesini kapsar:

$\Delta \mathrm{y}_{\mathrm{t}}=\mathrm{c}_{0}+\sum_{\mathrm{m}=1}^{\mathrm{n}} \mathrm{g}_{\mathrm{m}} \sin (2 \pi \mathrm{mt} / \mathrm{T})+\sum_{\mathrm{m}=1}^{\mathrm{n}} \mathrm{h}_{\mathrm{m}} \cos (2 \pi \mathrm{mt} / \mathrm{T})+\mathrm{v}_{\mathrm{t}}$

Sonrasında 3. denklemde verilen regresyondan elde edilen tahminler kullanılarak aşağıdaki regresyon uygulanir:

$\tilde{\mathrm{S}}_{\mathrm{t}}=\mathrm{y}_{\mathrm{t}}-\hat{\mathrm{c}}_{0} \mathrm{t}-\sum_{\mathrm{m}=1}^{\mathrm{n}} \hat{\mathrm{g}}_{\mathrm{m}} \sin (2 \pi \mathrm{mt} / \mathrm{T})+\sum_{\mathrm{m}=1}^{\mathrm{n}} \hat{\mathrm{h}}_{\mathrm{m}} \cos (2 \pi \mathrm{mt} / \mathrm{T})$

$\mathrm{S}_{\mathrm{t}}$ nin detrend seri olduğu yerde $\mathrm{m}$, yaklaşık değer için seçilen frekansı temsil eder.

Birim kök testi (Fourier ADF), takip eden regresyon tahmin edilerek uygulanır.

$\Delta \mathrm{y}_{\mathrm{t}}=\theta \tilde{\mathrm{S}}_{\mathrm{t}-1}+\lambda_{0}+\sum_{\mathrm{m}=1}^{\mathrm{n}} \lambda_{1 \mathrm{i}} \Delta \sin (2 \pi \mathrm{mt} / \mathrm{T})+\sum_{\mathrm{m}=1}^{\mathrm{n}} \lambda_{2 \mathrm{i}} \Delta \cos (2 \pi \mathrm{mt} / \mathrm{T})+\varepsilon_{\mathrm{t}}$

Bir birim kökünün boş hipotezi $\mathrm{H}_{0}:(\theta=0)^{\prime}$ dır ve $\tau_{\mathrm{LM}}$ tarafından verilen bir Lagrange Multiplier (LM) test istatistiğiyle analiz edilir. Analiz soucunda, boş hipotezin reddedilmesi serinin durağan olduğu anlamına gelir. Serideki hatalar arasında korelasyon ilişkisi olması durumunda, $\Delta \mathrm{yt}_{\mathrm{t}}$ nin gecikmeli değeri regresyona eklenerek artıkların beyaz kirlilik olması sağlanır. Eldeki gözlem sayısının sınırlaması dikkate alındığında, $\mathrm{n}$ $=\mathrm{m}=1$ ayarı seçilir. Enders ve Lee (2012)'in vurguladığı gibi, $\mathrm{m}=1$ kullanan bir fourier formu, bilinmeyen formdaki kırılmalara makul bir yaklaşım olarak hizmet edebilir (Ghoshray ve diğ., 2018). Fourier birim kök testleri sonucunda değişkenlerin durağan olduğu gözlenirse; değişkenler Fourier-VAR modeline seviye halleriyle dahil edilir. Entegre olduğu gözlenen değişkenlerin durağanlaştırılması için farkları alınır. Değişkenler bir w't vektöründe yığılır ve doğrusal VAR formu alır:

$\mathrm{w}_{\mathrm{t}}=\mathrm{B}_{0}+\sum_{\mathrm{i}=1}^{\mathrm{l}} \mathrm{B}_{1} \mathrm{w}_{\mathrm{t}-\mathrm{i}}+\mathrm{e}_{\mathrm{t}}$

Denklemde $B_{0}$ bir kesişme vektörü, $B_{i}$ koefisyen matrisiyken et hata terimlerinin bir vektörüdür. Gecikme uzunluğu I, Akaike Bilgi Kriterine (AIC) göre seçilir. Fourier Formu için, VAR modeli şöyle hesaplanır:

$\mathrm{w}_{\mathrm{t}}=\mathrm{B}_{0}(\mathrm{t})+\sum_{\mathrm{i}=1}^{\mathrm{l}} \mathrm{B}_{1} \mathrm{w}_{\mathrm{t}-\mathrm{i}}+\mathrm{e}_{\mathrm{t}}$

$\mathrm{B}_{0}(\mathrm{t})=\left\{\delta_{1}(\mathrm{t}), \delta_{2}(\mathrm{t}), \delta_{3}(\mathrm{t})\right]^{\prime}$ regresyonunda, her bir sabit $\delta_{i}(\mathrm{t})$, n'deki fourier kesişme noktasına bağlıdır:

$\delta_{i}(t)=x_{i}+b_{i} t+\sum_{m=1}^{n} x_{i m} \sin (2 \pi m t / T)+\sum_{m=1}^{n} x_{i k} \cos (2 \pi m t / T)$

Bir Fourier-VAR modeli, modelin düzgün yapısal farklılıklar olup olmadığını test edebilir. Özellikle de hesaba katılmayıp, dikkate alınmayan birçok yapısal kırılmayla, Granger nedensellik testleri zayıf olma eğilimindedir (Ghoshray ve diğ., 2018). Dolayısıyla Fourier-VAR modeliyle yapısal kırılma içerebilecek verileri de test edilebildiği için daha güvenilir sonuçlar ortaya koymaktadır (Ögel ve Gökgöz, 2020).

\subsection{Veri Seti ve Uygulama}

Çalışma için kullanılan veri seti Ocak 2003 ile Ocak 2018 dönemini kapsayan aylık verilerden oluşur. Veri setini oluşturan değişkenler katılım bankaları ortalama 1, 3, 6 ve 12 ay vadeli kar payı oranları, geleneksel 
bankalar 1, 3, 6 ve 12 ay vadeli ağırlıklı ortalama faiz oranları, TÜFE (tüketici fiyat endeksi), USD/TL döviz kurudur.

Uygulama dönemi için kar payı oranları verileri TKBB internet sitesinden ülkemizde faaliyet gösteren 3 katılım bankasının aylık kar payı oranlarının ortalamasının alınması suretiyle elde edilmiştir. Geleneksel bankaların ağırlıklı ortalama faiz oranları ve USD/TL döviz kuru verileri TCMB-EVDS sisteminden, TÜFE aylık verileri ise TUIK internet sitesinden edinilmiştir.

Çalışmada, zaman serisi analizlerinin yapılabilmesi için öncelikle serilerin durağanlığı test edilmiştir. Çalışmada doğal logaritmaları alınan serilerin birim kök içerip içermediğinin analizinde sıfır hipotezi $\left(\mathrm{H}_{0}\right)$ 'seri birim köktür' olan yapısal kırılmasız ADF (Dickey ve Fuller, 1981), yapısal kırılmaları dikkate alan tek kırılmalı ADF (Zivot ve Andrews, 1992), çift kırılmalı ADF (Narayan ve Pop, 2010), Fourier yaklaşımlı ADF (Enders ve Lee, 2012) testleri ve sıfır hipotezi $\left(\mathrm{H}_{0}\right)$ 'seri durağandır' yapısal kırılmasız KPSS (Kwiatskowski ve diğ., 1992), tek kırılmalı KPSS (Kurozumi, (2002), çift kırılmalı KPSS (CS ve Sanso, 2007), Fourier yaklaşımlı KPSS (Becker ve diğ., 2006) testleriyle analiz edilmiştir. Analiz sonucunda tüm değişkenlerin aynı seviyede durağan olduğu ( $\left.\mathrm{I}_{1}\right)$ ve eş bütünleşme analizi için değişkenlerin aynı seviyede durağan olma şartının sağlamış olduğu gözlenmiştir. 1, 3, 6 ve 12 ay vadeli kar payı oranları bağımlı değişkenlerinin; 1, 3, 6 ve 12 ay vadeli faiz oranları, TÜFE ve USD/TL döviz kurları bağımsız değişkenleri ile eşbütünleşme ilişkisi Gregory ve Hansen (1996) tarafından geliştirilen tek kırılmalı eş bütünleşme analizi uygulanmıştır. Sonraki aşamada seriler arasındaki kısa vadeli ilişkinin tespiti için, Fourier (yumuşak kırılma) Granger Nedensellik (Enders ve Jones, 2016) analizi kar payı ve faiz oranları arasında çift yönlü; USD/TL ve TÜFE'den kar payı oranlarına doğru tek yönlü test edilmiştir.

\section{BULGULAR}

Serilere birim kök/durağanlık analizi yapılmadan önceden serilerin doğal logaritmaları alınmıştır.
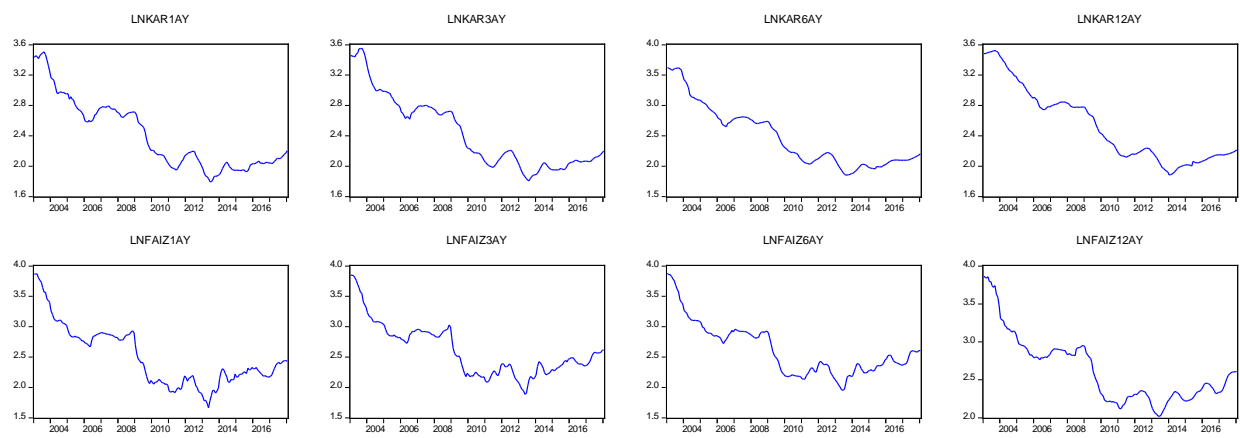

LNFAIZZAY
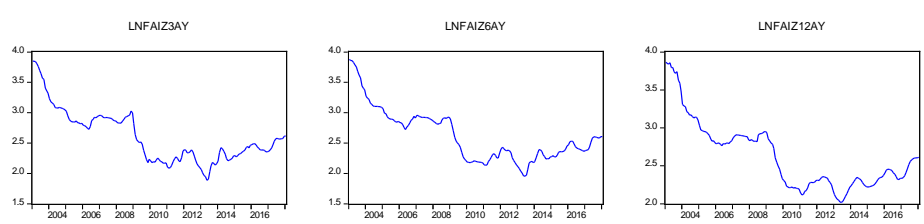

LNKUR
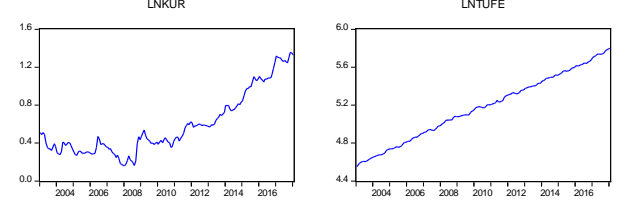

Şekil 1. Değişkenlerin Eğilim Grafiği

Doğal logaritmaları alınan serilere ilişkin tanımlayıcı istatistikler aşağıdaki tabloda sunulmuştur:

Tablo 1. Değişkenlere İlişkin Tanımlayıcı İstatistikler

\begin{tabular}{|l|c|c|c|c|c|}
\hline Değişkenler & Ortalama & Medyan & Maximum & Minimum & Standart Sapma \\
\hline LKAR1AY & 2.402 .406 & 2.180 .344 & 3.506 .781 & 1.794 .927 & 0.456165 \\
\hline LKAR3AY & 2.431 .013 & 2.198 .180 & 3.553 .237 & 1.808 .784 & 0.471116 \\
\hline LKAR6AY & 2.473 .156 & 2.223 .914 & 3.623 .120 & 1.850 .474 & 0.496174 \\
\hline LKAR12AY & 2.520 .608 & 2.316 .093 & 3.524 .150 & 1.885 .357 & 0.482138 \\
\hline
\end{tabular}


M. K. Çonkar - H. Gökgöz 13/1 (2021) 235-251

\begin{tabular}{|l|l|l|l|l|l|}
\hline LFAIZ1AY & 2.496 .302 & 2.315 .501 & 3.869 .742 & 1.665 .818 & 0.491921 \\
\hline LFAIZ3AY & 2.603 .147 & 2.477 .378 & 3.849 .722 & 1.885 .553 & 0.426456 \\
\hline LFAIZ6AY & 2.618 .436 & 2.486 .572 & 3.880 .326 & 1.954 .445 & 0.428380 \\
\hline LFAIZ12AY & 2.624 .962 & 2.457 .021 & 3.865 .351 & 2.018 .895 & 0.440956 \\
\hline LKUR & 0.585796 & 0.464030 & 1.357 .390 & 0.162192 & 0.322857 \\
\hline LTUFE & 5.176 .670 & 5.182 .008 & 5.801 .363 & 4.551 .453 & 0.348072 \\
\hline
\end{tabular}

Doğal logaritmaları alınan serilere yapısal kırılmasız ve yapısal kırılmalı birim kök ve durağanlık testleri uygulanmıştır. Serilerin seviyede sabit ve trendli model sonuçları ile 1. farklarında sabit model sonuçları raporlanmıştır.

Tablo 2. Yapısal Kırılmasız Birim Kök/Durağanlık Testleri

\begin{tabular}{|l|c|c|c|c|}
\hline \multirow{2}{*}{ Değişken } & \multicolumn{2}{|c|}{ Seviye-Sabit ve Trend Model } & \multicolumn{2}{c|}{ 1. Fark-Sabit Model } \\
\cline { 2 - 5 } & ADF & KPSS & ADF & KPSS \\
\hline Kar1ay & -1.447949 & 0.285836 & $-6.520764^{* * *}$ & $0.390238^{* * *}$ \\
\hline Kar3ay & -1.584861 & 0.301114 & $-4.820272^{* * *}$ & $0.380010^{* * *}$ \\
\hline Kar6ay & -1.560876 & 0.317031 & $-4.120526^{* * *}$ & $0.515171^{*}$ \\
\hline Kar12ay & -0.949219 & 0.312132 & $-3.999944^{* * *}$ & $0.503628^{*}$ \\
\hline Faiz1ay & -2.090127 & 0.326862 & $-7.894083^{* * *}$ & $0.537731^{*}$ \\
\hline Faiz3ay & -2.224574 & 0.318176 & $-7.098703^{* * *}$ & $0.571622^{*}$ \\
\hline Faiz6ay & -2.274821 & 0.325034 & $-5.928287^{* * *}$ & $0.523088^{*}$ \\
\hline Faiz12ay & -1.698824 & 0.310803 & $-6.920719^{* * *}$ & $0.537577^{*}$ \\
\hline Kur & -2.275222 & 0.401575 & $-9.732962^{* * *}$ & $0.521295^{*}$ \\
\hline TÜFE & -2.545272 & 0.216618 & $-10.13025^{* * *}$ & $0.156309^{* * * *}$ \\
\hline
\end{tabular}

Not: ADF testinde maksimum gecikme uzunluğu 13 olarak belirlenmiş olup oto korelasyon kontrolü için Schwarz bilgi kriterinden yararlanılmıştır. KPSS testinde oto korelasyon kontrolü için Barlet Kernel yöntemiyle Newey-West-Bandwith kullanılmıştır. ADF testinde sabit modeli için kritik değerler \%1, \%5 ve \%10 düzeylerinde sırasıyla; -3,466994, -2.877544 ve -2.575381'dir; sabit ve trend modeli için kritik değerler \%1, \%5 ve \%10 düzeylerinde sırasıyla; $-4,01143,-3.435125$ ve 3.141565 ' dir. KPSS testinde sabit modeli için kritik değerler \%1, \%5 ve \%10 düzeylerinde sırasıyla; $0.347,0.463$ ve 0.739 ' dur;

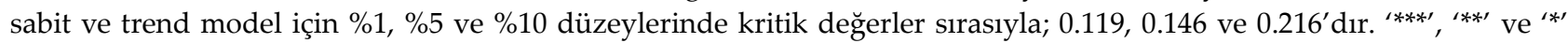
işaretleri sırasıyla \%1, \%5 ve \%10 düzeylerinde anlamlılığı göstermektedir.

Yapısal kırılmasız birim kök durağanlık testlerine ilişkin tablo incelendiğinde tüm serilerin aynı seviyede ve farkları alındığında durağan olduğu (I1) gözlenmiştir. 
M. K. Çonkar - H. Gökgöz 13/1 (2021) 235-251

Tablo 3a. Yapısal Kırılmalı Birim Kök Testleri

\begin{tabular}{|c|c|c|c|c|c|c|c|}
\hline Değişken & $\begin{array}{l}\text { Birim Kök } \\
\text { Testleri }\end{array}$ & $\begin{array}{c}\text { Tek } \\
\text { kırılmalı } \\
\text { ADF }\end{array}$ & $\begin{array}{c}\text { Kirilma } \\
\text { Tarihi }\end{array}$ & $\begin{array}{c}\text { Çift } \\
\text { Kirılmalı } \\
\text { ADF }\end{array}$ & $\begin{array}{c}1 . \\
\text { Kirilma } \\
\text { Tarihi }\end{array}$ & $\begin{array}{c}2 . \\
\text { Kırılma } \\
\text { Tarihi }\end{array}$ & $\begin{array}{c}\text { Fourier } \\
\text { ADF }\end{array}$ \\
\hline \multirow{2}{*}{ Kar1ay } & $\begin{array}{l}\text { Seviye-Kirilmalı } \\
\text { Sabit ve Trend } \\
\text { Model }\end{array}$ & -3.4916 & $\begin{array}{c}\text { Haziran } \\
2009\end{array}$ & -4.2258 & $\begin{array}{l}\text { Nisan } \\
2006\end{array}$ & $\begin{array}{c}\text { Haziran } \\
2009\end{array}$ & -3.1034 \\
\hline & \begin{tabular}{|l|} 
1. Fark-Kırılmalı \\
Sabit Model
\end{tabular} & $-5.6182^{* * *}$ & $\begin{array}{c}\text { Kasım } \\
2008 \\
\end{array}$ & $-7.3761^{* * * *}$ & $\begin{array}{c}\text { May1s } \\
2009 \\
\end{array}$ & $\begin{array}{c}\text { Temmuz } \\
2009 \\
\end{array}$ & $-3.6048^{* * *}$ \\
\hline \multirow[t]{2}{*}{ Kar3ay } & $\begin{array}{l}\text { Seviye-Kırılmalı } \\
\text { Sabit ve Trend } \\
\text { Model } \\
\end{array}$ & -3.8888 & $\begin{array}{c}\text { May1s } \\
2009\end{array}$ & -5.1524 & $\begin{array}{c}\text { Haziran } \\
2006\end{array}$ & $\begin{array}{l}\text { Ekim } \\
2012\end{array}$ & -2.7797 \\
\hline & \begin{tabular}{|l|} 
1. Fark-Kırılmalı \\
Sabit Model \\
\end{tabular} & $-5.9943^{* * *}$ & $\begin{array}{l}\text { Ekim } \\
2008 \\
\end{array}$ & $-6.5212^{* * * *}$ & $\begin{array}{c}\text { Haziran } \\
2006 \\
\end{array}$ & $\begin{array}{c}\text { Mayis } \\
2012 \\
\end{array}$ & $-3.9534^{* *}$ \\
\hline \multirow[t]{2}{*}{ Kar6ay } & $\begin{array}{l}\text { Seviye-Kırılmalı } \\
\text { Sabit ve Trend } \\
\text { Model } \\
\end{array}$ & -3.2202 & $\begin{array}{c}\text { Haziran } \\
2009\end{array}$ & -4.3816 & $\begin{array}{c}\text { Haziran } \\
2006\end{array}$ & $\begin{array}{l}\text { Ekim } \\
2012\end{array}$ & -3.6008 \\
\hline & $\begin{array}{l}\text { 1. Fark-Kırılmalı } \\
\text { Sabit Model }\end{array}$ & $-5.4004^{* * * *}$ & $\begin{array}{l}\text { Ekim } \\
2008\end{array}$ & $-6.1057^{* * *}$ & $\begin{array}{l}\text { Nisan } \\
2006\end{array}$ & $\begin{array}{c}\text { Haziran } \\
2006\end{array}$ & $-4.8630^{+20 x}$ \\
\hline \multirow[t]{2}{*}{ Kar12ay } & $\begin{array}{l}\text { Seviye-Kırılmalı } \\
\text { Sabit ve Trend } \\
\text { Model } \\
\end{array}$ & -2.8834 & $\begin{array}{c}\text { Haziran } \\
2009\end{array}$ & -3.9912 & $\begin{array}{c}\text { Haziran } \\
2006\end{array}$ & $\begin{array}{l}\text { Ocak } \\
2013\end{array}$ & -3.5159 \\
\hline & $\begin{array}{l}\text { 1. Fark-Kırılmalı } \\
\text { Sabit Model }\end{array}$ & $-6.6671^{* * *}$ & $\begin{array}{l}\text { Ekim } \\
2008\end{array}$ & $-7.4221^{* * *}$ & $\begin{array}{l}\text { Mart } \\
2006\end{array}$ & $\begin{array}{c}\text { Kasim } \\
2013\end{array}$ & $-3.3744^{*}$ \\
\hline
\end{tabular}

Not: Birim kök testlerinde maksimum gecikme uzunluğu 12 olarak ayarlanmış olup, optimal gecikme uzunluğu t-stat değeriyle belirlenmiştir. Fourier testlerde maksimum frekans sayısı 3 olarak ayarlanmış olup, optimal frekans kalıntıların karelerinin minimum toplamı tarafından belirlenmiştir.

Kırılmalı Sabit Modelde Kritik Değerler: Tek kırılmalı ADF: -5.3400 (\%1), -4.8000 (\%5), -4.5800 (\%10). Çift Kırılmalı ADF: $4.6720(\% 1),-4.0810(\% 5),-3.7720(\% 10)$. Fourier ADF: $-4.3100(\% 1),-3.7500(\% 5),-3.4500$ (\%10).

Kırılmalı Sabit ve Trend Modelde Kritik Değerler: Tek kırılmalı ADF : -5.57 (1\%), -5.08 (5\%), -4.82 (10\%). Çift Kırılmalı ADF: $-5.576(1 \%),-4.937(5 \%),-4.596(10 \%)$. Fourier ADF: $-4.43(1 \%),-4.38(5 \%),-3.77(10 \%)$.

Tablo 3b. Yapısal Kırılmalı Birim Kök Testleri

\begin{tabular}{|c|c|c|c|c|c|c|c|}
\hline Değişken & $\begin{array}{l}\text { Birim Kök } \\
\text { Testleri }\end{array}$ & $\begin{array}{c}\text { Tek } \\
\text { kırılmalı } \\
\text { ADF } \\
\end{array}$ & $\begin{array}{l}\text { Kırılma } \\
\text { Tarihi }\end{array}$ & $\begin{array}{c}\text { Çift } \\
\text { Kırılmalı } \\
\text { ADF } \\
\end{array}$ & $\begin{array}{c}1 . \\
\text { Kirilma } \\
\text { Tarihi } \\
\end{array}$ & $\begin{array}{c}2 . \\
\text { Kirılma } \\
\text { Tarihi } \\
\end{array}$ & $\begin{array}{c}\text { Fourier } \\
\text { ADF }\end{array}$ \\
\hline \multirow{2}{*}{ Faiz1ay } & $\begin{array}{l}\text { Seviye-Kirılmalı } \\
\text { Sabit ve Trend } \\
\text { Model }\end{array}$ & $-5.2041^{* *}$ & $\begin{array}{c}\text { Kasım } \\
2008\end{array}$ & $-5.7046^{* * *}$ & $\begin{array}{l}\text { Nisan } \\
2006\end{array}$ & $\begin{array}{c}\text { Kasım } \\
2008\end{array}$ & -3.6193 \\
\hline & $\begin{array}{l}\text { 1. Fark-Kırılmalı } \\
\text { Sabit Model }\end{array}$ & $-5.5960^{* * * *}$ & $\begin{array}{l}\text { Eylül } \\
2008 \\
\end{array}$ & $-9.5855^{* * *}$ & $\begin{array}{l}\text { Ekim } \\
2008 \\
\end{array}$ & $\begin{array}{c}\text { Aralık } \\
2008 \\
\end{array}$ & $-4.5401^{* *+*}$ \\
\hline \multirow[t]{2}{*}{ Faiz3ay } & $\begin{array}{l}\text { Seviye-Kırılmalı } \\
\text { Sabit ve Trend } \\
\text { Model } \\
\end{array}$ & $-5.4334^{* *}$ & $\begin{array}{c}\text { Kasım } \\
2008\end{array}$ & $-6.1240^{* * *}$ & $\begin{array}{l}\text { Nisan } \\
2006\end{array}$ & $\begin{array}{l}\text { Ekim } \\
2008\end{array}$ & -1.3395 \\
\hline & $\begin{array}{l}\text { 1. Fark-Kırılmalı } \\
\text { Sabit Model }\end{array}$ & $-8.1738^{* * * *}$ & $\begin{array}{l}\text { Eylül } \\
2008 \\
\end{array}$ & $-8.8403^{* * *}$ & $\begin{array}{l}\text { Eylül } \\
2008 \\
\end{array}$ & $\begin{array}{c}\text { Ağustos } \\
2009 \\
\end{array}$ & $-4.6860^{2+*+}$ \\
\hline \multirow[t]{2}{*}{ Faiz6ay } & $\begin{array}{l}\text { Seviye-Kırılmalı } \\
\text { Sabit ve Trend } \\
\text { Model }\end{array}$ & $-5.1943^{* *}$ & $\begin{array}{c}\text { Aralık } \\
2008\end{array}$ & $-5.6907^{* * *}$ & $\begin{array}{l}\text { Nisan } \\
2006\end{array}$ & $\begin{array}{c}\text { Aralık } \\
2008\end{array}$ & -3.3890 \\
\hline & $\begin{array}{l}\text { 1. Fark-Kırılmalı } \\
\text { Sabit Model }\end{array}$ & $-4.7067^{*}$ & $\begin{array}{l}\text { Eylül } \\
2008\end{array}$ & $-7.1434^{* * *}$ & $\begin{array}{l}\text { Ekim } \\
2008\end{array}$ & $\begin{array}{l}\text { Ağustos } \\
2009\end{array}$ & $-4.1945^{* * *+}$ \\
\hline
\end{tabular}


M. K. Çonkar - H. Gökgöz 13/1 (2021) 235-251

\begin{tabular}{|c|c|c|c|c|c|c|c|}
\hline \multirow[t]{2}{*}{ Faiz12ay } & $\begin{array}{l}\text { Seviye-Kırılmalı } \\
\text { Sabit ve Trend } \\
\text { Model }\end{array}$ & -4.1703 & $\begin{array}{l}\text { Nisan } \\
2009\end{array}$ & $-4.8890^{*}$ & $\begin{array}{l}\text { Ekim } \\
2004\end{array}$ & $\begin{array}{l}\text { Nisan } \\
2009\end{array}$ & -3.2650 \\
\hline & $\begin{array}{l}\text { 1. Fark-Kırılmalı } \\
\text { Sabit Model }\end{array}$ & $-5.2769^{* *}$ & $\begin{array}{l}\text { Eylül } \\
2008\end{array}$ & $-5.8690^{* * * *}$ & $\begin{array}{l}\text { Eylül } \\
2008\end{array}$ & $\begin{array}{l}\text { Mart } \\
2014\end{array}$ & $-3.4421^{* * *}$ \\
\hline \multirow[t]{2}{*}{ Kur } & $\begin{array}{l}\text { Seviye-Kırılmalı } \\
\text { Sabit ve Trend } \\
\text { Model }\end{array}$ & -4.7750 & $\begin{array}{c}\text { May1s } \\
2010\end{array}$ & $-6.6719^{* * *}$ & $\begin{array}{c}\text { Temmuz } \\
2008\end{array}$ & $\begin{array}{l}\text { Ağustos } \\
2012\end{array}$ & -0.9376 \\
\hline & $\begin{array}{l}\text { 1. Fark-Kırılmalı } \\
\text { Sabit Model }\end{array}$ & $-10.2536^{* * *}$ & $\begin{array}{c}\text { Haziran } \\
2008\end{array}$ & $\begin{array}{c}- \\
11.4399^{* * * *}\end{array}$ & $\begin{array}{c}\text { Haziran } \\
2008\end{array}$ & $\begin{array}{c}\text { Kasım } \\
2008\end{array}$ & $-5.1879^{* * *}$ \\
\hline \multirow[t]{2}{*}{ TÜFE } & $\begin{array}{l}\text { Seviye-Kırılmalı } \\
\text { Sabit ve Trend } \\
\text { Model }\end{array}$ & $-5.9032^{* * * *}$ & $\begin{array}{l}\text { Nisan } \\
2010\end{array}$ & $-7.2774^{* * *}$ & $\begin{array}{l}\text { Şubat } \\
2009\end{array}$ & $\begin{array}{c}\text { Haziran } \\
2016\end{array}$ & $-4.2728^{*}$ \\
\hline & $\begin{array}{l}\text { 1. Fark-Kırılmalı } \\
\text { Sabit Model }\end{array}$ & $-10.1700^{* * * *}$ & $\begin{array}{c}\text { Temmuz } \\
2016 \\
\end{array}$ & $\begin{array}{c}- \\
10.3940^{* * * *} \\
\end{array}$ & $\begin{array}{l}\text { Ağustos } \\
2008 \\
\end{array}$ & $\begin{array}{l}\text { Şubat } \\
2012\end{array}$ & $0.0519^{* * *+}$ \\
\hline
\end{tabular}

Tablo 4a. Yapısal Kırılmalı Durağanlık Testleri

\begin{tabular}{|c|c|c|c|c|c|c|c|}
\hline Değişken & $\begin{array}{l}\text { Durağanlık } \\
\text { Testleri }\end{array}$ & $\begin{array}{c}\text { Tek } \\
\text { Kırılmalı } \\
\text { KPSS }\end{array}$ & $\begin{array}{l}\text { Kırılma } \\
\text { Tarihi }\end{array}$ & $\begin{array}{c}\text { Çift } \\
\text { Kırrlmalı } \\
\text { KPSS }\end{array}$ & $\begin{array}{c}1 . \\
\text { Kirılma } \\
\text { Tarihi }\end{array}$ & $\begin{array}{c}2 . \\
\text { Kirlma } \\
\text { Tarihi }\end{array}$ & $\begin{array}{l}\text { Fourier } \\
\text { KPSS }\end{array}$ \\
\hline \multirow{2}{*}{ Kar1ay } & $\begin{array}{l}\text { Seviye-Kirılmalı } \\
\text { Sabit ve Trend } \\
\text { Model }\end{array}$ & 0.3695 & $\begin{array}{l}\text { Ağustos } \\
2013\end{array}$ & 0.4925 & $\begin{array}{c}\text { Temmuz } \\
2006\end{array}$ & $\begin{array}{l}\text { Eylül } \\
2009\end{array}$ & 0.4675 \\
\hline & $\begin{array}{l}\text { 1. Fark-Kırılmalı } \\
\text { Sabit Model }\end{array}$ & $0,0966^{* * *}$ & $\begin{array}{c}\text { Aralık } \\
2008\end{array}$ & 0,8617 & $\begin{array}{c}\text { Temmuz } \\
2003\end{array}$ & $\begin{array}{l}\text { Nisan } \\
2004\end{array}$ & 0.9492 \\
\hline \multirow[t]{2}{*}{ Kar3ay } & $\begin{array}{l}\text { Seviye-Kırılmalı } \\
\text { Sabit ve Trend } \\
\text { Model }\end{array}$ & 0.3676 & Ekim 2013 & 0.4778 & $\begin{array}{l}\text { Ağustos } \\
2006\end{array}$ & $\begin{array}{l}\text { Ekim } \\
2009\end{array}$ & 0.4660 \\
\hline & $\begin{array}{l}\text { 1. Fark-Kırılmalı } \\
\text { Sabit Model }\end{array}$ & $0.1143^{* * *}$ & $\begin{array}{c}\text { Aralık } \\
2008\end{array}$ & 0.9992 & $\begin{array}{l}\text { Ağustos } \\
2003\end{array}$ & $\begin{array}{c}\text { Haziran } \\
2004\end{array}$ & 1.0883 \\
\hline \multirow[t]{2}{*}{ Kar6ay } & $\begin{array}{l}\text { Seviye-Kırılmalı } \\
\text { Sabit ve Trend } \\
\text { Model }\end{array}$ & 0.5065 & $\begin{array}{c}\text { Kasım } \\
2013\end{array}$ & 0.2987 & $\begin{array}{l}\text { Ekim } \\
2006\end{array}$ & $\begin{array}{l}\text { Ocak } \\
2014\end{array}$ & 0.5342 \\
\hline & $\begin{array}{l}\text { 1. Fark-Kırılmalı } \\
\text { Sabit Model } \\
\end{array}$ & $0.1311^{* * * *}$ & $\begin{array}{c}\text { Aralık } \\
2008 \\
\end{array}$ & 1.5048 & $\begin{array}{l}\text { Ekim } \\
2003 \\
\end{array}$ & $\begin{array}{l}\text { Nisan } \\
2004\end{array}$ & 1.6460 \\
\hline \multirow[t]{2}{*}{ Kar12ay } & $\begin{array}{l}\text { Seviye-Kırılmalı } \\
\text { Sabit ve Trend } \\
\text { Model }\end{array}$ & 0.4652 & Nisan 2014 & 0.3458 & $\begin{array}{l}\text { Ocak } \\
2007\end{array}$ & $\begin{array}{l}\text { Nisan } \\
2014\end{array}$ & 0.5679 \\
\hline & $\begin{array}{l}\text { 1. Fark-Kırılmalı } \\
\text { Sabit Model }\end{array}$ & $0.1659^{* * * *}$ & $\begin{array}{l}\text { Aralık } \\
2008\end{array}$ & 0.3668 & $\begin{array}{l}\text { Ekim } \\
2012\end{array}$ & $\begin{array}{c}\text { Aralık } \\
2013\end{array}$ & 1.8799 \\
\hline
\end{tabular}

Not: Fourier testlerde maksimum frekans sayısı 3 olarak ayarlanmış olup, optimal frekans kalıntıların karelerinin minimum toplamı tarafından belirlenmiştir. Durağanlık testlerinde Barlet Spektral tahmini kullanılmıştır.

Kırılmalı Sabit Modelde Kritik Değerler: Tek Kırılmalı KPSS: 0.4827 (\%1), 0.3021 (\%5), 0.2291 (\%10). Çift Kırılmalı KPSS: 0.3009 (\%5). Fourier: 0.1295 (\%1), 0.1704 (\%5), 0.2706 (\%10).

Kırılmalı Sabit ve Trend Modelde Kritik Değerler: Tek Kırılmalı KPSS: 0.0649(10\%), 0.0789 (5\%), 0.1131 (1\%). Çift Kırılmalı KPSS: 0.0966 (5\%). Fourier KPSS: 0.0716 (1\%), 0.0546 (5\%), 0.0471 (10\%). 
M. K. Çonkar - H. Gökgöz 13/1 (2021) 235-251

Tablo 4b. Yapısal Kırılmalı Durağanlık Testleri

\begin{tabular}{|c|c|c|c|c|c|c|c|}
\hline Değişken & $\begin{array}{l}\text { Durağanlık } \\
\text { Testleri }\end{array}$ & $\begin{array}{c}\text { Tek } \\
\text { Kırılmalı } \\
\text { KPSS }\end{array}$ & $\begin{array}{l}\text { Kırılma } \\
\text { Tarihi }\end{array}$ & $\begin{array}{c}\text { Çift } \\
\text { Kırılmalı } \\
\text { KPSS }\end{array}$ & $\begin{array}{c}1 . \\
\text { Kırılma } \\
\text { Tarihi }\end{array}$ & $\begin{array}{c}2 . \\
\text { Kirılma } \\
\text { Tarihi }\end{array}$ & $\begin{array}{c}\text { Fourier } \\
\text { KPSS }\end{array}$ \\
\hline \multirow{2}{*}{ Faiz1ay } & $\begin{array}{l}\text { Seviye-Kırılmalı } \\
\text { Sabit ve Trend } \\
\text { Model }\end{array}$ & 0.4562 & $\begin{array}{l}\text { Ağustos } \\
2009\end{array}$ & 0.3798 & $\begin{array}{l}\text { Eylül } \\
2004\end{array}$ & $\begin{array}{l}\text { Temmuz } \\
2009\end{array}$ & 0.4220 \\
\hline & $\begin{array}{l}\text { 1. Fark-Kırılmalı } \\
\text { Sabit Model }\end{array}$ & $0.1676^{* * *}$ & Ekim 2008 & $0.1679^{* *}$ & $\begin{array}{c}\text { Nisan } \\
2013 \\
\end{array}$ & $\begin{array}{l}\text { Şubat } \\
2014 \\
\end{array}$ & 0.8891 \\
\hline \multirow[t]{2}{*}{ Faiz3ay } & $\begin{array}{l}\text { Seviye-Kırılmalı } \\
\text { Sabit ve Trend } \\
\text { Model }\end{array}$ & 0.4492 & $\begin{array}{l}\text { Ağustos } \\
2009\end{array}$ & 0.3526 & $\begin{array}{c}\text { Haziran } \\
2004\end{array}$ & $\begin{array}{l}\text { Temmuz } \\
2009\end{array}$ & 0.3995 \\
\hline & $\begin{array}{l}\text { 1. Fark-Kırılmalı } \\
\text { Sabit Model }\end{array}$ & $0.1958^{* *}$ & Ekim 2008 & 0.4669 & $\begin{array}{c}\text { Kasım } \\
2008\end{array}$ & $\begin{array}{l}\text { Şubat } \\
2009\end{array}$ & 0.9283 \\
\hline \multirow[t]{2}{*}{ Faiz6ay } & $\begin{array}{l}\text { Seviye-Kırılmalı } \\
\text { Sabit ve Trend } \\
\text { Model }\end{array}$ & 0.4623 & Eylül 2009 & 0.3702 & $\begin{array}{c}\text { Temmuz } \\
2004\end{array}$ & $\begin{array}{c}\text { Temmuz } \\
2009\end{array}$ & 0.4070 \\
\hline & $\begin{array}{l}\text { 1. Fark-Kırılmalı } \\
\text { Sabit Model }\end{array}$ & $0.2181^{* *}$ & $\begin{array}{c}\text { Kasım } \\
2008\end{array}$ & 0.3695 & $\begin{array}{c}\text { Aralık } \\
2008\end{array}$ & $\begin{array}{l}\text { Ekim } \\
2009\end{array}$ & 1.2674 \\
\hline \multirow[t]{2}{*}{ Faiz12ay } & $\begin{array}{l}\text { Seviye-Kirılmalı } \\
\text { Sabit ve Trend } \\
\text { Model }\end{array}$ & 0.5483 & $\begin{array}{l}\text { Kasım } \\
2009\end{array}$ & 0.4023 & $\begin{array}{l}\text { Mart } \\
2005\end{array}$ & $\begin{array}{l}\text { Eylül } \\
2009\end{array}$ & 0.4858 \\
\hline & $\begin{array}{l}\text { 1. Fark-Kırılmalı } \\
\text { Sabit Model }\end{array}$ & $0.2081^{* *}$ & $\begin{array}{c}\text { Kasım } \\
2008\end{array}$ & 1.1875 & $\begin{array}{l}\text { Ağustos } \\
2003\end{array}$ & $\begin{array}{c}\text { Aralık } \\
2003\end{array}$ & 1.4210 \\
\hline \multirow[t]{2}{*}{ Kur } & $\begin{array}{l}\text { Seviye-Kırılmalı } \\
\text { Sabit ve Trend } \\
\text { Model }\end{array}$ & 0.3938 & Eylül 2010 & 0.1396 & $\begin{array}{l}\text { Eylül } \\
2008\end{array}$ & $\begin{array}{l}\text { May1s } \\
2013\end{array}$ & 0.3739 \\
\hline & $\begin{array}{l}\text { 1. Fark-Kırılmalı } \\
\text { Sabit Model }\end{array}$ & $0.0432^{* * *}$ & $\begin{array}{c}\text { Temmuz } \\
2008\end{array}$ & $0.1181^{* * * *}$ & $\begin{array}{l}\text { Ağustos } \\
2008\end{array}$ & $\begin{array}{l}\text { Ekim } \\
2008\end{array}$ & $0.1132^{* * * *}$ \\
\hline \multirow[t]{2}{*}{ TÜFE } & $\begin{array}{l}\text { Seviye-Kırılmalı } \\
\text { Sabit ve Trend } \\
\text { Model }\end{array}$ & 0.1755 & May1s 2010 & 0.0961 & $\begin{array}{l}\text { Mart } \\
2009\end{array}$ & $\begin{array}{c}\text { Aralık } \\
2016\end{array}$ & 0.1498 \\
\hline & $\begin{array}{l}\text { 1. Fark-Kırılmalı } \\
\text { Sabit Model }\end{array}$ & $0.0206^{* * * *}$ & Nisan 2008 & $0.1030^{* * * *}$ & $\begin{array}{c}\text { Ağustos } \\
2011 \\
\end{array}$ & $\begin{array}{l}\text { Ekim } \\
2011 \\
\end{array}$ & $0.0519^{* * * *}$ \\
\hline
\end{tabular}

Yapısal kırılmalı birim kök ve durağanlık testlerine ilişkin tablolar incelendiğinde serilerin genel anlamda aynı seviyede ve farkları alındığında durağan (Iı) olduğu tespit edilmiştir. Aynı seviyede durağan olan seriler arasındaki uzun dönemli ilişkinin tespiti için öncelikle eşbütünleşme analizi yapılacaktır. 1, 3, 6 ve 12 ay vadeli kar payı oranları bağımlı değişkenlerinin; 1, 3, 6 ve 12 ay vadeli mevduat bankaları ağırlıklı ortalama faiz oranları, USD/TL döviz kuru ve TÜFE bağımsız değişkenleriyle olan uzun vadeli ilişkisi için katılım payı ve faiz oranlarının vadelerine göre 4 farklı model kurulmuş ve Gregory ve Hansen (1996) tarafından geliştirilen tek kırılmalı eşbütünleşme analiziyle test edilmiştir. 
M. K. Çonkar - H. Gökgöz 13/1 (2021) 235-251

Tablo 5. Tek Kırılmalı Eşbütünleşme Testi

\begin{tabular}{|c|c|c|c|c|c|c|c|c|c|c|}
\hline \multicolumn{11}{|c|}{ Seviye } \\
\hline \multirow{4}{*}{$\begin{array}{c}\text { Bağımlı } \\
\text { Değ. }\end{array}$} & \multirow{3}{*}{\multicolumn{2}{|c|}{ Kırılma Tarihi }} & \multicolumn{4}{|c|}{$\mathrm{ADF}$} & \multicolumn{4}{|c|}{ Z } \\
\hline & & & \multirow{3}{*}{$\begin{array}{c}\text { İst. } \\
\text { Değer }\end{array}$} & \multicolumn{3}{|c|}{ Kritik Değerler } & \multirow{3}{*}{$\begin{array}{c}\text { İst. } \\
\text { Değer }\end{array}$} & \multicolumn{3}{|c|}{ Kritik Değerler } \\
\hline & & & & \multirow[t]{2}{*}{$\% 1$} & \multirow[t]{2}{*}{$\% 5$} & \multirow[t]{2}{*}{$\% 10$} & & \multirow[t]{2}{*}{$\% 1$} & \multirow[t]{2}{*}{$\% 5$} & \multirow[t]{2}{*}{$\% 10$} \\
\hline & $\mathrm{ADF}$ & $\mathrm{Z}$ & & & & & & & & \\
\hline Kar 1 ay & $07 / 2013$ & $07 / 2013$ & $-5,101$ & $-6,05$ & $-5,57$ & $-5,31$ & $-35,78$ & $-70,18$ & $-59,4$ & $-54,38$ \\
\hline Kar 3 ay & $06 / 2010$ & $08 / 2010$ & $-5,349^{*}$ & $-6,05$ & $-5,57$ & $-5,31$ & $-30,352$ & $-70,18$ & $-59,4$ & $-54,38$ \\
\hline Kar 6 ay & $10 / 2013$ & $05 / 2007$ & $-4,085$ & $-6,05$ & $-5,57$ & $-5,31$ & $-27,137$ & $-70,18$ & $-59,4$ & $-54,38$ \\
\hline Kar 12 ay & $06 / 2011$ & $05 / 2015$ & $-4,632$ & $-6,05$ & $-5,57$ & $-5,31$ & $-22,931$ & $-70,18$ & $-59,4$ & $-54,38$ \\
\hline \multicolumn{11}{|c|}{ Rejim } \\
\hline \multirow{3}{*}{$\begin{array}{c}\text { Bağımlı } \\
\text { Değ. }\end{array}$} & \multirow{2}{*}{\multicolumn{2}{|c|}{ Kırılma Tarihi }} & \multicolumn{4}{|c|}{ ADF } & \multicolumn{4}{|c|}{$Z$} \\
\hline & & & \multirow{2}{*}{$\begin{array}{c}\text { İst. } \\
\text { Değer }\end{array}$} & \multicolumn{3}{|c|}{ Kritik Değerler } & İst. & \multicolumn{3}{|c|}{ Kritik Değerler } \\
\hline & ADF & $\mathrm{Z}$ & & $\% 1$ & $\% 5$ & $\% 10$ & Değer & $\% 1$ & $\% 5$ & $\% 10$ \\
\hline Kar 1 ay & $07 / 2013$ & $08 / 2013$ & $-5,644$ & $-6,92$ & $-6,41$ & $-6,17$ & $-58,229$ & $-90,35$ & $-78,52$ & $-72,56$ \\
\hline Kar 3 ay & $03 / 2007$ & $10 / 2008$ & $-5,315$ & $-6,92$ & $-6,41$ & $-6,17$ & $-34,494$ & $-90,35$ & $-78,52$ & $-72,56$ \\
\hline Kar 6 ay & $05 / 2007$ & $10 / 2008$ & $-4,499$ & $-6,92$ & $-6,41$ & $-6,17$ & $-25,665$ & $-90,35$ & $-78,52$ & $-72,56$ \\
\hline Kar 12 ay & $07 / 2015$ & $11 / 2005$ & 5,030 & $-6,92$ & $-6,41$ & $-6,17$ & $-23,588$ & $-90,35$ & $-78,52$ & $-72,56$ \\
\hline
\end{tabular}

Not: ${ }^{* * * \prime, ~}{ }^{* * \prime}$ ve ${ }^{* \prime}$ işaretleri sirasıyla \%1, \%5 ve \%10 düzeylerinde anlamlılı̆̆ı göstermektedir. Kritik değerler Gregory ve Hansen (1996)'nın 'Residual Based Tests for Cointegration in Models with Regime Shifts' çalışmasından elde edilmiştir.

Tek kırılmalı eşbütünleşme testi (Gregory ve Hansen, 1996) sonuçlarına göre 1, 3, 6 ve 12 ay vadeli kar payı oranları bağımlı değişkenleriyle; 1, 3, 6 ve 12 ay vadeli faiz oranları, USD/TL döviz kuru ve TÜFE bağımsız değişkenleri arasında kurulan 4 farklı modelde de seviye ve rejim kırılmada eşbütünleşme ilişkisinin olmadığ1 gözlenmiştir. Seriler arasındaki kısa vadeli ilişkinin tespiti için serilerin durağan haliyle $\left(\mathrm{I}_{1}\right)$ Fourier Granger Nedensellik analizi yapılacaktır.

Tablo 6. Fourier Granger Nedensellik Testi Sonuçları

\begin{tabular}{|c|c|c|c|c|}
\hline Sıfır Hipotezi $\left(\mathrm{H}_{0}\right)$ & $\begin{array}{l}\text { Wald } \\
\text { İstatistikleri }\end{array}$ & $\begin{array}{l}\text { Asimptotik } \\
\text { p Değeri }\end{array}$ & $\begin{array}{l}\text { Bootsrap p } \\
\text { Değeri }\end{array}$ & Sonuç \\
\hline Faiz1ay $\_$Kar1ay & 58,515 & $0,00^{* * *}$ & $0,00^{* * * *}$ & Hipotez reddedilir. \\
\hline Kar1ay $>$ Faiz1ay & 11,742 & 0,467 & 0,486 & Hipotez kabul edilir. \\
\hline USD/TL Kar1ay & 19,684 & $0,073^{*}$ & $0,086^{*}$ & Hipotez kabul edilir. \\
\hline TÜFE $\Rightarrow$ Kar1ay & 12,558 & 0,402 & 0,427 & Hipotez kabul edilir. \\
\hline Faiz3ay $\longrightarrow$ Kar3ay & 65,016 & $0,00^{* * *+}$ & $0,00^{* * *}$ & Hipotez reddedilir. \\
\hline Kar3ay $\Longrightarrow$ Faiz3ay & 13,938 & 0,305 & 0,331 & Hipotez kabul edilir \\
\hline $\mathrm{USD} / \mathrm{TL} \Rightarrow$ Kar3ay & 13,807 & 0,313 & 0,310 & Hipotez kabul edilir. \\
\hline TÜFE Kar3ay & 18,074 & 0,113 & 0,130 & Hipotez kabul edilir. \\
\hline Faiz6ay $>$ Kar6ay & 28,150 & $0,005^{* * *}$ & $0,019^{* *}$ & Hipotez reddedilir. \\
\hline Kar6ay Faiz6ay & 16,381 & 0,174 & 0,187 & Hipotez kabul edilir. \\
\hline USD/TL Kar6ay & 16,629 & 0,164 & 0,178 & Hipotez kabul edilir. \\
\hline TÜFE $>$ Kar6ay & 11,583 & 0,480 & 0,463 & Hipotez kabul edilir. \\
\hline Faiz12ay / Kar12ay & 21,676 & $0,041^{* *}$ & $0,062^{*}$ & Hipotez reddedilir. \\
\hline Kar12ay $\Rightarrow$ Faiz12ay & 7,490 & 0,824 & 0,813 & Hipotez kabul edilir. \\
\hline USD/TL $\Rightarrow$ Kar1ay & 4,027 & 0,545 & 0,534 & Hipotez kabul edilir. \\
\hline TÜFE $>$ Kar1ay & 13,942 & 0,264 & 0,275 & Hipotez kabul edilir. \\
\hline
\end{tabular}

Not: ' $\longrightarrow$ ' Sembolü nedensel ilişkinin olmadığını ifade eden sıfır hipotezini; ‘***' ‘**’, ‘*’ işaretleri sırasıyla ‘\%1', ‘\%5’ ve ‘\%10’ anlamlılık düzeylerini göstermektedir. Analiz için maksimum frekans ve gecikme uzunluğu sırasıyla; 3 ve 12, en uygun frekans ve gecikme uzunluğuna karar verilirken ‘Akaike Bilgi Kriterinden' faydalanılmıştır. 
1, 3, 6 ve 12 ay vadeli mevduat faiz oranları ile $1,3,6$ ve 12 ay vadeli kar payı oranları arasındaki nedensel ilişki aynı vadeler arasında test edilmiştir ve test sonuçları tablo 6 ' da sunulmuştur. Ayrıca tablo 6' da USD/TL döviz kuru ve TÜFE değişkenlerinden 1, 3, 6 ve 12 ay vadeli kar payı oranlarına doğru nedensellik ilişkisi olup olmadığının test sonucu da gösterilmiştir. Yapılan Fourier Granger nedensellik analizi sonucu, 1, 3, 6 ve 12 av vadeli mevduat faizi oranlarından 1, 3, 6 ve 12 ay vadeli kar payı oranlarına tek yönlü nedensellik ilişkisinin olduğu gözlenirken; USD/TL döviz kuru ile TÜFE'den kar payı oranlarına doğru nedensellik ilişkisi olmadığ1 görülmüştür.

\section{EKONOMETRİK ANALİZ BULGULARINDAN HAREKETLE BANKACILIKLA İLGİLİ BİR DEĞERLENDİRME}

Gerek literatür taramasında gerekse bizim çalışmamızda ortaya çıkan sonuçlar her iki banka türünün kazancını ifade eden faiz ve vade farkının aynı yönde ve birbirine çok yakın biçimde seyrettiğini göstermektedir.

Bu durumdan hareketle birçok yazar; belirttiğimiz durumun ortaya çıktı̆̆g ' murabaha' uygulamasının aslında faizsiz bir yöntem olarak kabul edilmesi hususunu tartışmaktadırlar. Biz ise aynı gerçeğe diğer taraftan bakarak; devletin çok ciddi düzenlemeleri çerçevesinde faaliyet gösteren klasik bankalardaki mevduat ve kredi faizinin Kur'an-ı kerimde yasaklanan riba ile aynı şey olup olmadığının da tartışılmasının gerektiğini belirtmek istiyoruz. Kaldıki islam ülkelerinde faizsiz bankacılık olarak isimlendirilen katılım bankacılığı gibi bir uygulamanın daha ortaya çıkmadığı dönemlerde bu yönde görüş belirten alimlerin olduğunu biliyoruz. Bunlar arasında Abdülaziz Çaviş, Reşid Rıza, Devalibi, Senhuri, Mensurizade Said, İzmirli İsmail Hakkı, Fazlurrahman gibi isimler sayılabilir. Belirtilen alimler 'Kur'an'da yasaklanan ribanın katlı veresiye faizi olduğunu buna mukabil ilk akit sırasındaki fazlalığın (faizin) riba kapsamında olmadığını' belirtmişlerdir (Uludağ, 1988: 41-49). Uludağ ayrıca şunu da ifade etmektedir: "Şunu da ilave edelim ki, Kur'an'da riba ile ilgili tehditler ve gösterilen şiddet, Kur'an'ın haram kıldığı faiş faizle ilgili olup, haramlığında ihtilaf bulunmayan riba muamelelerini hedef almaktadır. Aksi halde bu tür muameleleri riba saymayan İbn Abbas ve Usame başta olmak üzere birçok ulema bu tehditlerin mevzusunu teşkil eder (Uludağ, 1988: 49).

Her çeşit banka faizinin İslam'ın yasakladığı riba olduğu biçimindeki anlayış ülkemizde genel kabul görmüş bakış açısı olarak belirtilebilir. Bu yöde görüş belirten gerek dini tahsil görmüş olanlar, gerekse ekonomi, işletme ve finans eğitimi almış olanların faizin haramlığı ve haramlığın gerekçeleri hususunda söyledikleri ve yazdıklarının özü ve özetini 20. yüzyıl Türkiye'sinin en önde gelen tefsir alimi Elmalı Hamdi Yazır'ın 'Hak Dini, Kur'an Dili' adlı tefsirinde bulabiliriz (Yazır, 1992, C2: 236-256). Tefsirdeki faiz yasağının gerekçelerine ilişkin açıklamalardan bir özetleme yapmakta yarar görüyoruz:

(1) Faizci borç verip riba alabilmek için daima bir muhtaç gözetir. Her riba ihtiyaç sahibinin ihtiyacını hafifletecek yerde onun emeğini ve üretimini karşılıksız gasp eder (C.2, s.240).

(2) Bunlar riba ile emek ve iş sahiplerinin çalışmalarının ürünü olan şeyi alıp onunla geçindiklerinden tembellik içinde yatar, rahat ve hızlı bir şekilde uyanamazlar, hemen kalkamazlar (C.2, S.241).

(3) Riba insanları cidden çalışıp kazanmak ve üretim ile meşgul olmaktan uzak tutar. Çünkü herhangi bir suretle beş on kuruş para sahibi olmuş bulunan bir kimse faizcilikle parasını peşin veya veresiye artırmak imkanı bulunca artık geçimini kazanmak için az veya çok kolay bir yol elde etmiş olur. Ve o zaman zahmetli olan ticaret ve sanatlarla çalışıp kazanmak zorluğuna ve sıkıntısına dayanamamaya başlar. Bu durum, yüksek üretim yapmaya kabiliyetli birçok kimsenin çalışmalarından iş dünyasının mahrum kalmasına ... sebep olur (C.2, s.249).

(4) Ribanın (faizin) yürürlükte olduğu yerlerde ... para sahipleri karz-ı hasenden vazgeçmeye başlarlar. Bu şekilde halk arasında iyilik, ihsan, yardımlaşma ve dayanışma duyguları silinmeye, yerine hırs, kin, öfke ve saldırganlık fikirleri yayılmaya yüz tutar (C.2, S.250).

Söz konusu eleştirilerin tümü iki taraflı borç verme ilişkisi çerçevesinde bir anlam ifade edebilir. Halbuki günümüzde faiz deyince banka dediğimiz kurumlar akla gelir öncelikle. Burada ise üç taraflı bir ilişki söz konusudur. Bankaya tasarruflarını yatıran mevduat sahipleri, aracı kurum olarak banka ve bankanın kredi verdiği işletme veya fertler. Buradaki faiz yasağına ilişkin gerekçeleri eleştirmeden önce söylenmesi gereken esas husus şudur: bütün bu ve benzeri eleştiriler klasik banka mevduat faizi ve kredi faiziyle ilgili olarak 
geçerliyse, faizsiz bankacılık yaptığı ifade edilen katılım bankalarının mevduata verdiği kar payı ve kredi kullandırmada uyguladığı vade farkının söz konusu olduğu 'murabaha' uygulaması için de aynen geçerlidir.

Burada ayrıca, yukarıda söz konusu tefsirden aktardığımız faizin yasaklanma gerekçeleri üzerinde de kısaca durmak gerektiğini düşünüyoruz. Yukarıda da ifade ettiğimiz gibi belirtilen gerekçelerin tümü iki taraflı borç verme ilişkisi çerçevesinde anlamlı olabilir. Ribanın yasaklandığı dönem ve ortamda borç veren zengin, borç alan ise fakir taraftır. Üstelik riba oranı da kontrolsüz biçimde yüksektir, hatta kat kattır. Dolayısıyla bu ilişkide genellikle zenginin fakiri zor duruma düşürmesi bir gerçektir. Bugünkü bankacılık sisteminde ise mevduat yatıranların, yani borç verenlerin önemli bir kısmı küçük tasarruf sahipleridir. Banka küçük tasarruflardan oluşan ciddi büyüklükteki fon havuzundan önemli bir kısmını üretim yapan işletmelere, bir kısmını ise fertlere borç olarak vermektedir. Yani borç verenler zenginler, borç alanlar fakirler biçiminde bir ilişki söz konusu olmadığı gibi, tersi de söylenebilir.

Mevudat yatıranların önemli bir kısmının tasarruf sahipleri olduğunu belirtmiştik. Burada geçim sağlamak veya zengin olmaktan ziyade ek bir getiri elde etmek amacının öne çıtığını söylemek daha gerçekçi bir değerlendirme olur.

Klasik bankalarda fon kullandırılırken, kullanacak olan işletmenin borç ödeme gücü, yönetiminin kalitesi, kredi verilecek alanın uygunluğu gibi değerlendirmeler yapılır. Olumsuz koşulların ödeme güçlüğüne düşürdüğü işletmeler için borcun yeniden yapılandırılması gibi yöntemlerle iyi niyetli işletmelere ödemede kolaylaştırıcı davranılabilir.

Bankaya yatırım amaçlı fon yatırma ile karz-ı haseni rakip olarak görmek pek doğru bir karşılaştırma olmaz. Birisinde amaç yatıım iken, diğerinde hayır işlemektir. Bankalara hayır amaçlı fon yatırıldığında (karz-1 hasen), bankaların bunları faizsiz olarak kullandırması teorik olarak mümkündür. Ancak karz-ı hasen daha çok birbirini tanıyan fertler arasında ve çok büyük olmayan tutarlarda olmaktadır. Finans kurumları aracılığıyla gerçekleştirilmesi zordur. Nitekim halen hiçbir katılım bankasında tüm ihtiyaç duyan kitleye yönelik Karz-1 Hasen uygulaması yoktur. Bu hususta 2019 yılında Afyon Kocatepe Üniversitesi Sosyal Bilimler Enstitüsünde yönettiğim "İslami Finans Aracı Olarak Karz-ı Hasen ve Katılım Bankaları İçin Bir Model Önerisi" başlıklı doktora tezine başvurulabilir.

Değerlendirmemizin başlangıcında da katılım bankacılığı uygulamasının başlamasından çok önceleri bile klasik bankalardaki mevduat ve kredi faizinin Kur'an'da yasaklanan riba ile aynı şey olmadığını savunan birçok alim olduğunu belirtmiştik. Katılım bankacılığının kredi kullandırma uygulamasının \%90'ından fazlasının 'murabaha' yöntemi olduğu, bu yöntemde ise bankaya fon yatıranlara ödenen kar payı ve kredi kullananlara uygulanan vade farkı oranlarının klasik banka mevduat ve kredi faizleriyle çok yakın ve aynı yönde seyrettiği gerçeğinin açık biçimde görülmesinden sonra bu değerlendirmenin daha da büyük önem kazandığını rahatlıkla söyleyebiliriz.

Katılım bankaları ile ilgili eleştirilerin özellikle "murabaha" yöntemi üzerinde yoğunlaştığını görmekteyiz. Murabaha esas olarak kısa vadeli fon ihtiyacının karşılanmasına, daha açıklayıcı ifadeyle "çalışma sermayesi'ndeki ani ve ekonomi veya sektördeki sıkıntı ve dalgalanmalar nedeniyle işletmenin iradesi dışında ortaya çıkan ihtiyaçların finanse edilmesi için kullanılan bir finansman yöntemidir.

Bu durumda katılım bankalarının fon kullandırma uygulamaları içinde çok geniş yer tutan murabahayı fıkhi açıdan eleştirenlerin şu soruya net bir cevap üretmeleri gerekmektedir: Kısa vadeli kredi için banka gibi bir kurum çerçevesinde murabaha'dan daha uygun bir "finansman yöntemi seçeneği" öneriyor musunuz? Aksi halde geleneksel bankaların devletin sıkı düzenlemeleri ve denetimi çerçevesinde yürüttükleri kısa vadeli kredi uygulamasındaki faizin riba olmadığıyla ilgili görüşlerini daha objektif ve önyargısız biçimde değerlendirilmesi gerekmez mi?

Bizi bu yönde bir tartışmanın anlamlı olacağı kanısına yönelten diğer bir hususun son zamanlarda ciddi din alimlerimizden bazılarının makale ve kitaplarındaki değerlendirmeleri olduğunu belirtmek isteriz. Ne demek istediğimizin daha iyi anlaşılabilmesi için söz konusu alimlerden bazı alıntıları ayrıca aktarmanın yararlı olacağını düşünüyoruz:

“Faiz meselesinde doğru ve kuşatıcı bilgi ve hükümler ortaya koyabilecek bir tek din alimimizin bile bulunmadığını, bulunamayacağını düşünüyorum. Çünkü yüzlerce yıldır bir arpa boyu yol alamamış 
olduğumuzdan da anlaşılabileceği üzere- mahiyeti gereği bu meselenin çözümünün ulema fetvalarından değil, ekonomi ve finans tarihi, felsefesi, pratiği gibi birçok konuda birçok uzmanın yapacakları bilimsel çalışmalarında aranması gerektiğini düşünüyorum." (Çağrıcı, Karar Gazetesi, 2020).

...Riba/faiz meselesinde din alimlerine düşen esas görev ise konunun teknik yanlarını ekonomi ve para uzmanlarına bırakıp, ilgili ayet ve hadisin dikkat çektiği asıl ilkeye yoğunlaşmak, yani sistemin zulüm ve mağduriyetler doğuracak şekilde uygulamasına karşı mücadele etmektir.' (Çağrıcı, Karar Gazetesi, 2020).

'Kur'an' da yasaklanan riba (cahiliye ribası) ile bugünkü bankacılık sisteminde bin bir türüyle cari olan faiz'i özellikle meşhur 'altı mal hadisinden hareketle gelişigüzel biçimde aynileştirmek pek mümkün değildir.... Çünkü 1400 küsür yılı öncesinin Medine pazarındaki piyasa, para, ticaret, iktisat ilişkilerinin o günden bugüne çok köklü paradigmatik evrimler geçirdiği izahtan varestedir. Bu mesele bir tarafa, Kur'an'da yasaklanan riba bugün 'yer altı tefeciliği' denen sistemdeki uygulamaya benzer şekilde cari olan mürekkep faizdir ki buna 'temerrüt/gecikme faizi de denilebilir. Öte yandan, riba, Kur'an'ın nazil olduğu dönemdeki ekonomik şartlar mucibince tefeci zenginlerin yoksul ve/veya ihtiyaç sahibi insanlara verdiği borçlarda cereyan eden birşeydir. Oysa modern bankacilık sisteminde çoğu kez zenginler kredi kullanan, küçük tasarruf sahipleri ise bankadaki mevduatlarıyla zenginleri fonlayan kimseler mesabesindedir.' (Öztürk, Karar Gazetesi, 2020).

‘Bankacılık ve faiz konusunun içinden çıkılmaz olmasının birçok sebebi arasında işaret etmemiz gereken bir tanesi varsa o da, İslam'ın ana kaynakları olan Kur'an ve Sünnetteki 'riba' yasağının nasıl yorumlanabileceği ... konusunda analitik bir tartışma açmaktan ya da bugün farklı ve yeni bir teori geliştirmenin imkanını konuşmaktan ısrarla kaçınmamızdır.

Sahih-i Buhari'nin ilk hadisi amellerin niyetlere bağlı olarak değer taşıdığına dairdir. ... Böyle olunca. Bu 'murabaha', 'sukuk', 'teverruk' gibi işlemlerin hakikatini, bir kredi usulü olup olmadığını lafı dolandırmadan ve birbirimizi kandırmadan ortaya koymamız gerekir. ... Fıkıh kitaplarına bakıldığında hiyel-i şer'iyyenin, yani kuralların arkasını dolanarak engellediği sonuca bir şekilde ulaşma çabasının en çok faiz ve talak alanlarında gündeme geldiği görülür' (Bardakoğlu, 2019: 253).

'Aslında bir alanda hiyelin çok ortaya çıkması, konulan kuralların hayatın tabii akışına ve olaylara cevap veremeyecek şekilde sıkıştığını ve daraldığını, eskiden çözüm için geliştirilen bir kuralın bugün sorun üretmeye başladığını gösterir'. (Bardakoğlu, 2019: 254).

'Öyleyse biz gerçek olmayan kuralın arkasını dolanma amaçlı hileli ve bazı şekli işlemleri niçin yapıyoruz? Cenab-1 Mevla biliyor, hepimiz biliyoruz ki biz gelen şahsa borç para/kredi vermek niyetindeyiz. O da bunun için geldi'. (Bardakoğlu, 2019: 256).

'Burada fıkıhcılara ve hepimize ve hepimize düşen görev İslam'ı şekle boğan, İslam'ın ruhunu ve özünü yitirten kalıplardan ve dar anlayışlardan kurtulmanın çaresine bakıp dinin aslına, dinin asıl mesajlarına uygun başka çıkış yollarının bulunup bulunmadığını sorgulamaktır. Bunun için daha derindeki meselelerin yöntem açısından, dinin temel ilke ve amaçları gözetilerek, tarih ve toplumsal değişim, bir de insanlığın ortak tecrübesi ciddiye alınarak tartışılmasına ihtiyaç vardır.' (Bardakoğlu, 2019: 257).

\section{SONUÇ VE TARTIŞMA}

Bu çalışmada, katılım bankaları kar payı oranları, geleneksel bankalar mevduat faiz oranları, TÜFE ve USD/TL döviz kuru arasındaki ilişki, yapısal kırılmaları dikkate alan birim kök, eşbütünleşme ve nedensellik analizleriyle test edilmiş ve uygulama sonucunda değişkenler arasında eşbütünleşme ilişkisi olmadığı; ancak aynı vadelerde, faiz oranlarından kar payı oranlarına doğru tek yönlü nedensel ilişki olduğu sonucuna ulaşılmıştır. Çalışmamız özellikle, katılım bankalar kar payı oranlarının geleneksel bankalar mevduat faiz oranlarından etkilendiğini göstermektedir. Elde edilen sonuçlar, literatürde İslami bankalar kar payı oranları ile geleneksel bankalar mevduat faizi oranları üzerine; Kaleem ve Isa (2003), Bacha (2004), Chong ve Liu (2009), Cevik ve Charap (2015) Topdağ ve Işık (2019), Tura ve Kaya (2019) tarafından yapılan çalışmaların bulgularıyla aynı doğrultudadır. Ayrıca çalışma bulgularından hareketle, katılım bankalarının faiz riskine maruz kaldığı ve faiz riskine karşı önlem alması gerektiği ve faizden kaçmak isteyen tasarruf sahipleri olan, katılım bankalarındaki mevduat sahiplerinin de katılım bankalarına yatırım yaparken TÜFE ve USD/TL döviz kuru gibi makro ekonomik değişkenlerden ziyade faizi göz önünde bulundurması gerektiği belirtilebilir. 
M. K. Çonkar - H. Gökgöz 13/1 (2021) 235-251

Literatürdeki çalışmalar yapısal kırılmaları dikkate almayan yöntemlerle analiz edilmiştir. Oysa yapısal kırılmaların dikkate alınmaması sonuçların gerçekten sapmasına neden olabilmektedir. Bu sebeple çalışmamızda yapısal kırılmaları dikkate alan yöntemlerin (Fourier birim kök testi, tek kırılmalı eşbütünleşme analizi ve Fourier Granger nedensellik analizi) kullanılması literatüre katkı sağlayacaktır.

Bu konuda yapılan çalışmaların çoğundan farklı olarak, bizim çalışmamızda; katılım bankaları vade farkları ve kar payı oranlarının, geleneksel bankaların faiz oranlarıyla aynı yönde hareket etmesi ve hemen hemen aynı olması ile ilgili bir değerlendirme de yapılmıştır. Bu olgudan hareketle konuyla ilgilenenlerin çoğu 'murabaha' yönteminin aslında faizsizlik iddiasına uymadığını ileri sürmektedir. Biz ise bu olguya ters yönden de bakılabileceğini, dolayısıyla devletin sıkı düzenlemeleri ve denetimi altında çalışan geleneksel bankaların kısa vadeli kredi uygulamasındaki faizin riba olup olmadığı tartışmasını da anlamlı kıldığını çalışmamızda gündeme getirmiş olduk.

\section{KAYNAKÇA}

Ata, H. A., Buğan, M. F. ve Çiğdem, Ş. (2016). Kar Payı Oranları İle Mevduat Faiz Oranları Arasındaki Nedensellik İlişkisi, Ç.Ü. Sosyal Bilimler Enstitüsü Dergisi, 25 (1), 17-28.

Avcı, T. ve Aktaş, M. (2015). Katılım Bankalarının Kar Payı Ödemeleri İle Mevduat Bankalarının Faiz Ödemelerinin Birbirlerine Yakın Olmasının Nedenlerinin Araştırılması, Niğde Üniversitesi İktisadi ve İdari Bilimler Fakültesi Dergisi, 8 (4), 41-51.

Bacha, O. I. (2004). Dual Banking Systems And Interest Rate Risk For Islamic Banks, The Journal of Accounting, Commerce \& Finance-Islamic Perspective, 1, 1-42.

Bardakoğlu, A. (2019). İslam’ı Doğru Anlıyor Muyuz?, İstanbul, Kuramer Yayını.

Becker, R., Enders, W., Lee, J. (2006). A Stationarity Test in The Presence of An Unknown Number of Smooth Breaks, J. Time Ser. Anal., 27 (3), 381-409.

Canbaz, Fatih, (2019). İslami Finans Aracı Olarak Karz-ı Hasen ve Katılım Bankaları için Bir Model Önerisi, Afyonkarahisar, Yayınlanmamış Doktora Tezi.

Carrion-I Sivestre, J. L. ve Sanso, A. (2005). The KPSS Test with Two Structural Breaks, Spanish Economic Review, 9 (2), 105-127.

Cevik, S. ve Charap, J. (2015). The Behavior of Conventional and Islamic Bank Deposit Returns in Malaysia and Turkey, International Journal of Economics and Financial Issues, 5(1), 111-124.

Chong, B. S. ve Liu, M. H. (2009). Islamic banking: Interest-Free or Interest-Based?, Pacific-Basin Finance Journal, 17 (1), 125-144.

Çağrıcı, M. (22.01.2020). Faiz ve Fetva, Karar Gazetesi.

Dickey, D. A. Ve Fuller, W. A. (1981). Likelihood Ratio Statistics for Autoregressive Time Series with a Unit Root, Econometria, 4, 1057-1072.

Enders, W. ve Jones, P. (2016). Grain Prices, Oil Prices and Multiple Smooth Breaks in a VAR, Studies in Nonlinear Dynamics \& Econometrics. 20 (4), 1-21.

Enders, W. Ve Lee, J. (2012). A unit root test using a Fourier Series to Approximate Smooth Smooth Breaks, Oxf. Bull. Econ. Stat., 74 (4), 574-599.

Gallant, A. (1981). On The Bias in Flexible Functional Forms and an Essentially Unbiased Form, Journal of Econometrics, 15 (2), 211-245.

Ghoshray, A., Mendoza, Y., Monfort, M. ve Ordoñez, J. (2018). Re-Assessing Causality between Energy Consumption and Economic Growth, PLoS ONE, 13 (11), 1-15.

Gregory, A. W. ve Hansen, B. E. (1996). Residual-Based Tests for Cointegration in Models with Regime Shifts, Journal of Econometrics, 70 (1), 99-126. 
M. K. Çonkar - H. Gökgöz 13/1 (2021) 235-251

Gül, M. E., Torun, T. ve Dumrul, C. (2017). Türk Katılım Bankalarının Fon Kaynaklarını Etkileyen Faktörler ve Bu Bankaların Klasik Bankalarla İlişkileri Üzerine Bir Uygulama, Erciyes Üniversitesi İktisadi ve İdari Bilimler Fakültesi Dergisi, 50, 141-166.

Haron, S. ve Ahmad, N. (2000). The Effects of Conventional Interest Rates and Rate of Profit on Funds Deposited With Islamic Banking System in Malaysia, International Journal of Islamic Financial Services, 1 (4), 1-7.

Ito, T. (2013). Islamic Rates of Return and Conventional Interest Rates in The Malaysian Deposit Market, International Journal of Islamic and Middle Eastern Finance and Management, 6 (4), 290-303.

Kaleem, A. ve Isa, M. M. (2003). Causal Relationship between Islamic and Conventional Banking Instruments in Malaysia, International Journal of Islamic Financial Services, 4 (4), 1-8.

Kurozumi, E. (2002). Testing for Stationary With A Break, Journal of Econometrics, 108, 63-99.

Kwiatkowsk1, D., Phillips, C. B., Schmidt, P., Shin, Y. (1992). Testing The Null Hypothesis of Stationary Against The Alternative of A Unit Root, Journal of Econometrics, 54, 159-178.

Minny, M. ve Görmüş, Ş. (2017). The Impact Of Interest Rate Fluctuations On The Participation Banks Profitability: Turkey Case, Uluslararası İslam Ekonomisi ve Finansı Araştırmaları Dergisi, 3 (2), 55-73.

Narayan, P. K. ve Popp, S. (2010). A New Unit Root Test with Two Structural Breaks in Level and Slope at Unknown Time, Journal of Applied Statistics, 37 (9), 1425-1438.

Ögel, S. ve Gökgöz, H. (2020). BİST 100 ve Katılım Endekslerinin Faiz ve Döviz Kurlarıyla İlişkisinin Analizi, Maliye ve Finans Yazlarn Dergisi, 114, 353-374.

Öztürk, M. (18.01.2020). Diyanet, Toki, Faiz, Karar Gazetesi.

Topdă̆, D. ve Işık, N. (2019). Katılım Bankacılığının Gelişimi ve Türkiye'deki Katılım Bankaları Üzerine Bir Nedensellik Analizi, Uluslararası İslam Ekonomisi ve Finansı Araştırmaları Dergisi, 5 (3), 65-86.

Tura, Ü. ve Kaya, F. (2019). Türkiye'de Katılım Bankaları Tarafından Katılma Hesaplarına Uygulanan Kar Payı Ödemeleri ile Geleneksel Bankalar Tarafından Mevduatlara Uygulanan Faiz Oranları Arasındaki İlişkininin Analizi, International Academic Journal, 3 (2), 187-202.

Uludağ,, S. (1988). İslamda Faiz Meselesine Yeni Bir Bakış, İstanbul, Dergah Yayınları.

Yazır, E. M. H. (1992). Hak Dini Kur'an Dili, Sadeleştirenler: İsmail Karaçam, Emin Işık, Nurettin Bolelli, Abdullah Yücel, İstanbul, Azim Dağıtım.

Zainol, Z. ve Kassim, S. (2010). An Analysis of Islamic Banks' Exposure to Rate of Return Risk, Journal of Economic Cooperation and Development, 31 (1), 59-84.

Zengin, N., Yıldız, Z. ve Sel, A. (2018). Katılım Bankalarının Dağıttığı Aylık Kâr Payı Oranlarının Karşılaştırmalı Analizi: (2010-2017), C.Ü. İktisadi ve İdari Bilimler Dergisi, 19 (2), 555-565.

Zivot, E., Andrews, D.W.K. (1992). Further Evidence on The Great Crash, The Oil-Price Shock and The UnitRoot Hypothesis, J. Bus. Econ. Stat. 10, 251-270. 